\title{
"Losing a Leg to Gain a Wife": Marriage, Gender, and the Prosthetic Body Part
}

\author{
False rumps, false teeth, false hair, false faces, \\ Alas! poor man! how hard thy case is; \\ Instead of WOMAN-beavenly woman's charms, \\ To clasp cork, gum, wool, whalebone in his arms. \\ —“Made-up Beauty,” The Botanico-Medical Recorder 8, no. 2
} (1839): 30.

These lines from "Made-up Beauty," a poem that was first printed in the New York Atlas and then in the Botanico-Medical Recorder and the Graham Journal of Health (all in 1839), brings to the fore one of the common ways that gender inflected representations of prostheses in nineteenthcentury Britain and America. In this example, men are portrayed as victims within a world increasingly filled with "false" females-women made up with various forms of cosmetic prostheses. This poem, on the one hand, draws from wider concerns about prostheses as devices that fraudulently mask physical aberrances-features that the physiognomically minded thought, if read correctly, could reveal character and behavioural traits. On the other, "Made-up Beauty" exposes specific concerns about the popularity of certain kinds of artificial body parts among women. These forms of artifice, which include dentures, wigs, and "false rumps" (a padded cushion-like accessory that was worn by women under their dresses) as well as makeup, are portrayed as robbing men of "woman's charms," by

(C) The Author(s) 2022

R. Sweet, Prosthetic Body Parts in Nineteenth-Century Literature and Culture, Palgrave Studies in Nineteenth-Century Writing and Culture, https://doi.org/10.1007/978-3-030-78589-5_5 
which the speaker appears to mean organic idiosyncrasies. The comment "how hard thy case is" has a double meaning, referring to both the supposedly unfortunate situation faced by men and the lamentable physical hardness or otherwise unhuman nature of some of the materials that were used to make prostheses: "cork," which many wrongly thought was used to make false limbs; "gum," which was used to make false teeth; wool, which was used to make false rumps; and "whalebone," which was used to make corsets and some high-end artificial legs. ${ }^{1}$ The gendered focus of this poem, which looks at women from a male perspective, thus shows how certain types of prosthesis were associated with particular genders (cosmetic devices with female users) and how negatively these items could be received when detected. But how proscribed were stereotypes regarding prosthesis users? How were male and female prosthesis users represented in literary works that centred on romantic relationships between men and women? What do these representations tell us about attitudes to physical wholeness and difference and how they were inflected by gender?

This chapter traces representations of male and female prosthesis users in the marriage plot, the nineteenth-century narrative form most heavily populated by users of prosthetic devices. Building on the work of scholars such as Martha Stoddard Holmes and Talia Schaffer, who have brought attention to propensity for disabled figures to appear in Victorian marriage plots (a trope that has been labelled by Schaffer as "disability marriage"), I identify the prosthesis-marriage plot as a related yet separately identifiable formulaic narrative structure. ${ }^{2}$ As I argue, when viewed collectively, and at times also individually, prosthesis-marriage plots presented unstable affective and imaginative treatments of prosthesis users. These representations shed light on the complex ways in which discourses of gender, class, and ableism intersected and how, in particular instances, the bodily status quo was challenged, brought into question, or even outright rejected. There were certainly fixed and distinct ideas associated with male and female prosthesis users. Nonetheless, prosthesis-marriage plots sometimes exploited and at other times interrogated these dominant attitudes.

The present chapter adds further nuance to the rich body of scholarship that centres on the Victorian marriage plot. From the seminal studies of Ian Watt and Lawrence Stone-which position representations of modern loving marriages as direct results of the rise of affective individualism in the seventeenth century - through Nancy Armstrong's ground-breaking work (which argues that eighteenth- and nineteenth-century marriage plots translated political tensions into personal desire) to more recent and 
revisionist appraisals, it is safe to say that the richness of the marriage plot as a literary mode has been matched by the vast amount of scholarship that has covered it. ${ }^{3}$ But what has research in this field had to say about the prevalence of physical difference in nineteenth-century marriage plots? What do disability marriage plots tell us about contemporary attitudes to physical difference?

These questions have been partially addressed in recent studies by Cindy LaCom, Martha Stoddard Holmes, and Talia Schaffer, though fictional prosthesis users remain under-researched. ${ }^{4}$ LaCom, Holmes, and Schaffer draw attention to the varied and profound ways the Victorian marriage plot grappled with the topic of disability. LaCom's 1997 essay "Is It More than Lame" explores the different attitudes and stereotypes associated with disabled women in terms of sexuality and motherhood. She argues that by reading Victorian writings about disabled women in both a literal and a metaphorical way, we can gain critical insights into not only gendered attitudes towards disability, but also an understanding of how woman's "nature" and "passion" have been historically constructed. Holmes builds on this work, focusing on the "melodramatization" of disability in the marriage plot. ${ }^{5}$ She argues that melodramatic disability marriage plots of Edward Bulwer-Lytton, Charles Dickens, Dinah Mulock Craik, and Charlotte M. Yonge served a double function: these narratives "work[ed] through nondisabled women's desire, ... imagin[ing] the happy realms of able-bodied love by warning of the miseries that lay outside it"; they also "introduce[ed] and attempt[ed] to 'normalize' a number of potentially startling notions about disabled women." Holmes, however, also reveals how Wilkie Collins positioned the disabled heroines of his sensation-fiction novels Hide and Seek (1854) and Poor Miss Finch (1872) as "direct challenges to melodramatic modes of representing disability." Collins's disabled heroines transgressively express sexual desire and are, in the case of Lucilla Finch, procreative, in a manner that counters nineteenth-century marital norms.

Schaffer's more recent argument encompasses disability marriage but also refigures the way that we think about the Victorian marriage plot more broadly. Schaffer identifies the "familiar marriage" in the Victorian novel as a prevalent yet overlooked marital model that competed with romantic marriage, the form that has dominated the historiography of marriage heretofore. Schaffer explains that familiar marriage developed out of the eighteenth-century ideal of marrying for rational esteem rather than for romantic love, but, unlike the older model, it was predicated by 
existing affection. Familiar marriage, as it was imagined in literature, provided individuals an organic community and domestic influence, life choices that romantic marriage often failed to offer. ${ }^{8}$ Regarding disability, Schaffer argues:

[T] he disabled subject of the nineteenth century was the center of a social network. Because a disabled person required carers, this person was normally surrounded by others: parents, friends, servants, nurses. For a lonely person, a disabled partner could be the entry into a ready-made world, offering the intimate community ties for which so many Victorians yearned. ${ }^{9}$

Focusing primarily on the choices of nondisabled females, Schaffer explains that marriages with certain disabled male characters were attractive because of the social opportunities that they presented.

My discussion draws attention to the many instances where prosthesis users appear central to and sometimes disrupt the formulaic workings of the marriage plot. As I show, reflecting its status as a contested bodily device, the prosthesis was an unstable motif, at times facilitating either familiar or romantic marriage but at other times blockading the prospect of nuptials. Here, I begin by contextualizing gendered attitudes to physical difference and prosthesis use before parsing the various ways in which prosthesis users were represented in Victorian marriage plots. The literary investigation starts with depictions of prosthesis-using females and males whose prostheses are represented as obstacles to marital relations before investigating the various ways in which both male and female prosthesis users were imagined to be attractive. The sections that follow concentrate in turn on the sub-tropes of "love which conquers all reversals and disabilities," on devices that are alluring for economic reasons, on matches involving two prosthesis users, and on narratives that reject concealment and show prosthesis users as attractive on their own terms.

\section{Gendered Difference}

Before exploring gendered representations of prosthesis users in the marriage plot, it is first worth considering the different aspects that were at stake for men and women who lost body parts in the Victorian period. Although an appearance of physical wholeness was key for both men and women in this period, bodily losses were perceived to come at different 
costs for men and women. On the one hand, an impression of physical completeness was vital for men as it signalled moral integrity and social status; provided an index for youth and vitality (particularly in the case of teeth and hair); and distinguished them as individuals capable of working and thus accruing capital. ${ }^{10}$ Women, in particular single ones, on the other hand, were under pressure to look as physically whole as possible, for the most part, in order to either look eligible for marriage or so as to not place the reputations of their husbands and families into disrepute by displaying physical incompleteness. Social class, however, was a factor that complicated clear distinctions between the social protocols for male and female prosthesis users. Functionality rather than aesthetics tended to be a priority for both male and female prosthesis users at the lower end of the social ladder as the work that they relied upon to make a living usually involved hard physical labour. But since their employment depended on positive relations with middle- or upper-class employers, and because social aspirations encouraged many to copy the behaviours and attitudes of their social superiors, the working classes were not exempt from bourgeois bodily discourses.

In terms of how men were affected by attitudes to physical difference in relation to the marriage market, we learn from writings such as $A$ Narrative of the Experience and Sufferings of William Dodd, a Factory Cripple (1841) that the contemporary ableist masculine discourse of work also negatively impacted physically incomplete men's chances of marrying. ${ }^{11}$ Though primarily concerned with drawing to public view the atrocious working and living conditions that apprentice factory children were exposed to, Dodd's memoir also shed light on contemporary attitudes to physical difference. Notably, Dodd describes the resistance that he encountered from a couple of women whom he attempted to court. The first "was too wise to join her destinies with those of a factory cripple. She left the town, and refused to answer my letters, which was a sufficient reason for my discontinuing to write." 12 The second, a housekeeper, was initially open to his advances but he soon realized that she was not serious about marrying:

She would walk with me to church, to a place of amusement, to her relations to take tea, in the field, or anywhere but to the trap that I had baited for her. So I began to think that old birds were not to be caught with chaff. However, I did not like the idea of giving up to be laughed at, so I persevered, and pressed my suit more warmly, but soon found that she was only playing with me, like a cat with a mouse. ${ }^{13}$ 
Following this rejection, Dodd decided to give up on the hope of finding a partner and resigned himself to a life a bachelorhood. Though he was not a prosthesis user as such (owing most likely to the prohibitive cost and lack of functional use afforded by contemporary artificial arms), we learn about the difficulties that faced working-class amputee men wishing to marry. Key to the rejections that Dodd faced-in courtship as well as in his attempts to find work after his accident-was the assumption that, because he was missing a limb, he therefore lacked the necessary physical prowess to work to an acceptable standard and make a reasonable living. As indicated by his admission that his first lover "was too wise to join her destinies with those of a factory cripple" and his earlier claim that "to have married a factory girl, would only have involved both myself and her in greater troubles," Dodd viewed his own marital potential as diminished, underscoring the pervasive, insidious, and intersecting nature of ableist, masculinist, and capitalist discourses in this period. ${ }^{14}$

Men higher up the social ladder were also challenged by ableist attitudes associated with physical difference, though their chances of success were aided to some extent by their access to prosthetic body parts that could supposedly enable them to pass as normal. As Stephen Mihm notes, "[i]n an age of appearances, members of the middle classes necessarily hid their deformities and weaknesses, for fear that first impressions might deny them opportunities in marriage, employment, and social advancement."15 Responding to demands for concealment, the prosthesis industry in Britain and America saw an unprecedented expansion, producing a litany of devices that prioritized enabling users to appear whole. Commenting on the success of high-end American limb prostheses, while emphasizing the necessity for respectable men to hide their physical difference in the private as well as public sphere, in his 1864 essay "The Human Wheel, Its Spokes and Felloes," the American physician and poet Oliver Wendell Holmes famously called for "[limbs] which shall be presentable in polite society." Holmes explains that "misfortunes of a certain obtrusiveness may be pitied, but are never tolerated under the chandeliers." 16 While the focus of Holmes's comments is on limb amputees, his comments on the intolerability of "misfortunes of a certain obtrusiveness" clearly extend to other forms of physical difference, including the perceived absence of other body parts including eyes, teeth, and even hair. Highlighting the extent to which eye loss was castigated as unattractive within the middle-class home, in 1862 Parisian ocular prosthesis maker Auguste Boissonneau remarked that living with eye loss was particularly hard to bear for men "on account 
of the moral torture occasioned by the humiliations or self-imposed idea of repulsiveness to which the unfortunate person who has experienced such a loss is exposed." 17 Though marriage per se was not a direct focus of Boissonneau's comments, a lexis of desire infiltrates his comments: he uses the term "repulsiveness." His words thus draw attention to the view that disablist attitudes to ocular difference prevented men with one eye from securing partners in respectable society.

Social responses to physical difference often provided obstacles to women seeking marriage partners in this period. Much of the stigma that negatively affected women drew from fears of contagious and hereditary risk. Drawing from contentious medical debates surrounding contagion, suggestiveness, and transmission, Martha Stoddard Holmes explains that, according to the logic of the time, "any physical impairment had the potential to be perceived as transmissible by contact; by miasmatic air; by a combination of contact, environment, and individual constitution; or perhaps simply by the social class into which one was born." 18 Hereditary fears about the implications of having physically aberrant mothers often ruled women who had lost body parts out of marrying. Numerous cultural and medical sources from the 1830s onwards perpetuated degenerative fears about all manner of disabilities being hereditary conditions. The perceived risks of allowing the disabled to copulate were made explicit by prominent medical experts such as Henry Maudsley:

Certain unfavourable conditions of life tend unquestionably to produce degeneracy of the individual; the morbid predisposition so generated is thus transmitted to the next generation, and, if the unfavourable conditions continue, is aggravated in it; and thus is formed a morbid variety of the human kind, which is incapable of being a link in the line of progress of humanity. ${ }^{19}$

Such proto-eugenicist verdicts buttressed the troubling view that those exhibiting physical difference were not suitable marriage partners.

The fact that women, rather than men, were the primary focus of discussions of the supposed degenerative potential of disabled procreation brings to the fore a sexual double standard. In his study Intermarriage (1838), Alexander Walker stresses the sexual agency of men and focused attention on the need for women's bodies to be perfect: "the organization of the woman destined to reproduce, should be of the best kind; and that maturity, exercise and perfection in every function, are equally essential; for, as are these and their adaption to the male, so will be the perfection of 
the progeny." ${ }^{20}$ While Walker identifies the necessity for both the male and the female partner to be physically sound in order to create perfect progeny, two factors reveal a gendered discrepancy. First, the medicalized (male) focus of this piece is on the female body (the male body was very much a second thought here). Secondly, both the authorship and the intended audience of this piece-both male-point towards the comparative agency that men had when it came to choosing their partners compared to women. Women's freedom of choice was restricted by social, economic, and even legal factors. ${ }^{21}$

As numerous critics have noted, during this period women's bodies were a constant source of obsessive cultural and medical attention. ${ }^{22}$ Underlining the importance of physical beauty for women in this period, by the turn of the century, medical men, including Carl Heinrich Stratz and Havelock Ellis, were writing in detail about what constituted the perfect female body. ${ }^{23}$ Advertisements for certain kinds of prostheses, such as dentures, were directly targeted at women, exploiting their anxieties to look physically whole and thereby presentable (see Fig. 5.1). Thus, while physical appearance was also important for men-more so, as we have seen, for those of higher social standing-for women it was paramount across the classes since without it their pathway to marriage, the standard route to social and financial security in adult life, was obstructed.

A 1909 New York Times letter to the editor entitled "Damages for an Eye" reveals in regrettable tones the effect that the loss of just a single eye could have to an aspiring young woman even by the early twentieth century. ${ }^{24}$ Written by the aunt and guardian of a girl who lost an eye in a "street car collision," the piece argued that $\$ 4000$ - a figure equivalent to the "real wealth" value of $\$ 116,000$ in 2019 - which is the amount of compensation that the aunt's lawyers encourage her to aim for, was nowhere near enough to make up for the financial, social, educational, and potential medical implications of the niece's $\operatorname{loss}^{25}$ :

I think the accident has cut off her chances of ever marrying. No man would have her. Moreover, she has lost her judgment of distances, which will make her always clumsy in whatever occupation she may take up to support herself. On her blind side she is exposed to future accident, which she cannot be alert to guard against .... Her education is limited; the accident has handicapped her in acquiring more education. Her disfigurement has crushed her spirit-she feels ashamed, unfit to compete with people in the world. ${ }^{26}$ 


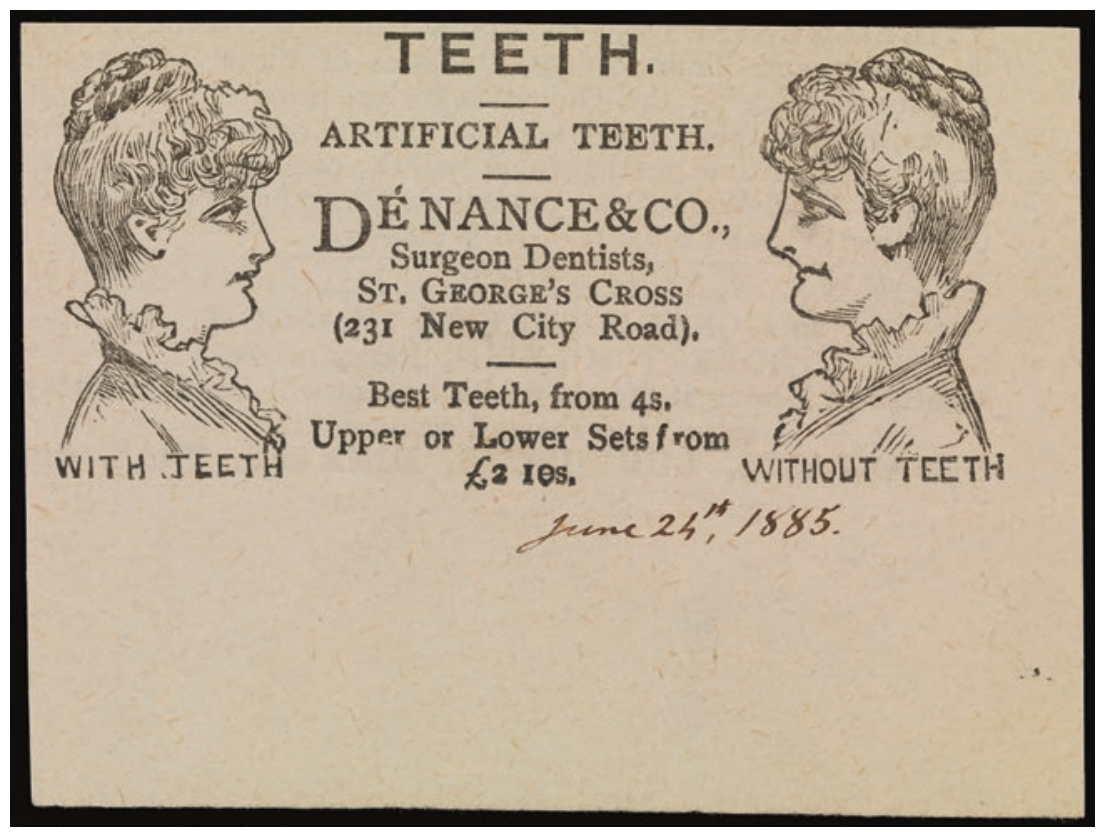

Fig. 5.1 An 1880s artificial teeth advertisement, depicting what a woman looks like with and without teeth. In the image without, her mouth looks noticeably sunken. Advertisement for Dénance \& Co. artificial teeth, 1885, Wellcome Collection, London. Image courtesy of the Wellcome Collection. https://wellcomecollection.org/works/wnvnhxje. CC BY 4.0

From this passage, we can see the perceived price of physical loss for a young woman. The fact that the niece's compromised marriageability was the aunt's first consideration reveals the different issues at stake for men and women who experienced serious physical injury. This distinction is compounded further by the shame that the victim felt, an emotional state that stemmed not solely from the disfigurement itself but also from the unaccepting response of her contemporary society-since she no longer fitted the beautiful, physically complete, feminine ideal and thus faced marginalization.

We can contrast these marital fears with the financially linked but somewhat different anxieties felt by men who had lost functional parts. In the Household Words short story "The Lame Landlord's Story" (1867), a 
former engine driver recalls his initial fears after "losing" a leg and badly injuring an arm in what was thought an accident (but, as we learn, was actually an attempted murder): "It stood to reason that I couldn't hope to drive, nor even stoke, engines any more, and it really seemed that as if I'd nothing but the workhouse or a street-crossing before me." Here, the amputee's fear is not that he will be unable to marry-though this is later a short-lived anxiety that is quashed when his beloved "sent word that she'd love [him] better, without legs or arms, than any one else." 27 Instead, his immediate anxiety is that he will not only lose his job but also be rendered unemployable. As we learn from sources such as Dodd's memoir, for working-class men there was a clear link between productive potential and marital success, a reality somewhat obscured by the sentimental tone of "The Lame Landlord's Story." Nevertheless, what sources like this one and the New York Times article indicate is that men and women who were missing body parts often held different, though clearly entangled, priorities. While it was paramount for working- and middle-class men to pass as productive (to maintain their social, economic, and sexual status as masculine breadwinners), for women of equivalent social standings, the priority was to pass aesthetically as normal (to deflect disablist-misogynist stigma and afford them the best possible chance of marrying advantageously).

However, the concept that prostheses could enable physically incomplete men and women to appear whole to eligible partners (including not just those who had had limbs amputated, but also those who lacked hair, were missing teeth, or who had lost eyes) proved a point of contention. William Blanchard Jerrold famously debated the virtues and vices of prostheses by identifying that some observers saw artificial body parts as "emblem[s] of deceit," "device[s] of ingenious vanity," or items that "cover[ed] the wearer with gross and unpardonable deceit." 28 Drawing from such claims, an 1861 Chambers's Journal fictional work, which purports to be a factual article, suggests that women, especially ones looking for partners, had less of a right than men to use prostheses:

I admit, if the lady I pay my addresses to has the misfortune to have one of her legs made of cork, I should prefer to be apprised of the fact before I put up the bans, rather than after the marriage-ceremony. Perhaps she, too, has some claim to be made acquainted with the circumstance, that my prepossessingly natural appearance is not altogether free from a certain alloy of unreality. But we will let that pass. ${ }^{29}$ 
This quotation draws our attention to the seemingly impossible position faced by a single woman who had lost a body part. While for her own sake, and her family's, a woman seen as incomplete would have likely faced significant pressure to use a prosthesis to mask her loss and thus hopefully attract a future husband, sources like this one imply that women should not try to deceive potential suitors. Yet this assertion is troubling when one considers the stigma that accompanied physical loss in this period. Men were encouraged to avoid copulating with physically aberrant women. Thus, women who were seen as deficient faced a conundrum: Did they use a prosthesis and risk discovery and subsequent accusations of fraudulence? Or did they give up on the possibility of marriage altogether and face an also stigmatized life of spinsterhood? Physically different men faced a similar problem but were less reliant on marrying for social and financial security, if they were deemed fit for work. As these situations reveal, life-shaping decisions about whether to use a prosthesis were at times informed less by impairment itself than by the social conditions that prohibited "intermarriage" with physically aberrant women and excluded non-normative bodies from the public sphere of work.

\section{Prostheses in the Marriage Plot}

\section{"False" Females}

As one can imagine, romantic relationships often do not proceed well for prosthesis users in nineteenth-century literary works. Many characters do not make it as far as engagement or even courtship. Pre-courtship narratives (i.e. short fictions centring on the early meetings of single subjects looking for prospective marital partners, such as those imagined in "Her Fatal Sneeze" [1890] and "The Stricken Fawn" [1893]), present prostheses as undesirable appendages that block potential paths to marriage. ${ }^{30}$ Prostheses are depicted as turnoffs, which if inopportunely revealed foreclose romantic attraction. In "Her Fatal Sneeze," which (though not illustrated) was published in the halfpenny comic Illustrated Chips, a seemingly attractive "young thing of about twenty-four" has a mishap at a party that transforms her in the minds of the men present from "the belle of the evening" to a woman who must be avoided at all costs. Initially, the young woman, whose name is withheld, appears remarkably attractive: she has "rich, red lips, bright, sparkling eyes, and pearly teeth." Her teeth in particular "cause her to be the centre of attraction" as they "occasionally 
showed themselves as she smiled during her animated conversation." However, her façade of a pristine image is ruptured when she sneezes. To the "frightful" shock of her pursuers, her teeth-which we learn are false-fall out and her eye, which we realize is made of glass, "popped halfway across the room." Somewhat cruelly, the narrator reports the result of these unfortunately timed bodily acts: "Somehow after that the men did not seem to appreciate her beauty, and she was left severely alone." 31

This unsympathetic treatment is symptomatic of both the popularity of cruel bodily humour, which followed the tradition set out by English jestbooks in the mid-eighteenth century, ${ }^{32}$ and wider prejudiced attitudes towards women, for whom physical blemishes were judged extremely harshly. Because of its low cost and accessible humour, Illustrated Chips was popular with working-class readers, at its height having a circulation of half a million..$^{33}$ The inclusion of satirized prosthesis users such as the false teeth user in this story shows how the failings of artificial body parts were considered humorous to working-class readers as well as those higher up the social ladder. What may have been particularly amusing to lowerclass readers was the representation of a respectable woman's false teethmost likely partial plates, which remained popular despite the advent of crowns and bridges-malfunctioning and causing a scene. Considering the still relatively (though no longer prohibitively) high commodity cost of artificial teeth in Britain in the 1890s-approximately $2 \mathrm{~s}$. per tooth or 10-11d. for a full set-we might consider "Her Fatal Sneeze" as an example of the masses mocking the codes and practices of the more affluent. ${ }^{34}$ In this regard, the sketch exposes the culture of using sophisticated, expensive prostheses to pass as a kind of folly, one always prone to catastrophe due to the social pressures involved: if one needs to use a prosthesis to pass as normal, then an unfortunate exposure will inevitably result in scandal.

Fun's "The Stricken Fawn," written for a more refined and affluent adult metropolitan middle-class readership, presents an even more hyperbolized story that emphasizes (and mocks) the shallowness of middle-class men, while utilizing the female prosthesis user for satirical purposes. Again, in this narrative, which positions itself as a parody of sentimental fiction, prostheses are obstacles to romantic relations, though here this representational model is also satirized. Set in the fictional seaside village "Drivelton-on-Sea," "The Stricken Fawn" pitches two sisters, Dolly and Dotty, against one another as potential wives for the absurdly named "Marquis of Puddlepond." The Marquis has the choice of Dolly, who is 
"weirdly beautiful" but compromised in terms of intellect (she stands at the window "catching flies") or Dotty, who is "intelligent" and "industrious," but "plain" due to her use of "the glass eye, false front, cork leg \&c., \&c." Faced with this choice, the Marquis selects the more physically conventional of the two sisters, Dolly, much to the disappointment of Dotty, who dies of heartbreak as a result. ${ }^{35}$ In a plot that comically exaggerates the formulaic features of popular narratives that engage disability, "The Stricken Fawn" blatantly mocks the sentimental mode, while using prostheses as a familiar comic trope. Holmes identifies how the "twin structure," which "pairs a disabled woman with a nondisabled one and gives them distinctly different physical, emotional, and marital futures" was a common melodramatic trope in Victorian marriage plots. ${ }^{36}$ This motif was clearly one of the satirical targets of "The Stricken Fawn."

A second obvious target was the image of the prosthesis as romantic obstacle, which is exposed as a related, hackneyed trope. The narrative treats both the "twin" and the prosthesis-as-romantic-obstacle structures with comic exaggeration. Dotty is not merely a false-teeth user but the user of many prosthetic devices - too many, it would seem, to be listed in entirety, as signified by the repetition of "\&c." In this regard, we once again find evidence of ableism's instability in depictions of the prosthetic: though the writing is somewhat disablist in its use of physical (and, as I will show, mental) difference for humour, comic scorn is directed towards the superficiality of privileging physical beauty, an ideal shown to rely on a conspicuously whole body. Certainly, by Victorian standards of female beauty, Dolly is the more physically attractive of the two sisters, but society's over-investment in appearances is mocked through her diminished cognitive capacity. Ableism, in this case a favouring of normative intellect, paradoxically destabilizes preferences for physical normalcy. The story thus raises the ethically loaded question: What is preferable, a cognitively impaired or physically incomplete wife? In this case, though we are encouraged to question his decision, the Marquis decides that cognitive impairment is preferable, drawing attention to, while also satirizing, the social ideal of the married woman as silent and passive.

In other nineteenth-century narratives, prostheses prove obstacles further down the path to marriage. For instance, "Too Hard upon My Aunt" (1863), A. M.'s "Was She False" (1875), and "Kitty the Careless" (1883) - published respectively in All the Year Round, The London Reader, and $J u d y$-use humour to communicate to diverse readerships advice regarding which prostheses women should avoid when looking for marital 
partners. ${ }^{37}$ A further notable work in which a prosthetic device becomes an obstacle to marriage is Thomas Hardy's The Woodlanders, which was first published serially in Macmillan's Magazine and Harper's Bazar from 1886 to $1887 . .^{38}$ In this "woodland story," which as Penny Boumelha observes, "giv[es] narrative form and textual representation to desire," 39 Felice Charmond (one of the novel's more unlikeable sexual transgressors) is eventually revealed to her adulterous lover, the also odious philosopherphysician Giles Fitzpiers, as a wig user. This revelation has disastrous consequences for their illicit affair.

Unlike other plots in which prosthesis use is withheld from the reader as well as the non-prostheticized party in the romance, in Hardy's novel dramatic irony is present throughout. ${ }^{40}$ As early as the second chapter, we witness the aptly named master barber Mr. Percomb, who we learn is employed by the affluent widow Mrs. Charmond, as he attempts to convince the rural peasant Marty South to part with her hair so that a wig can be made for his client. Part of the rhetorical strategy utilized by Percomb (whose name splices "peruke" and "hair comb") relies on the revelation of his client's identity: we learn that Mrs. Charmond has taken a fancy to Marty's abundant chestnut curls and that she is also, conveniently, Marty's father's landlady. Before the reader directly encounters Mrs. Charmond, our impression of her is already tarnished by the strong-arm tactics employed to procure Marty's hair and by the apparent reason for her wanting to attain a wig. As Marty explains herself: "She wants my curls to get another lover with; though if stories are true she's broke the heart of many a noble gentleman already." 41 Once the transaction is complete, which occurs after Marty realizes that her own romantic ambitions involving the apple picker Giles Winterborne are futile, she is sworn to secrecy regarding the identity of the new user of her hair. But this pact does not stop her from revealing this news much later in the narrative. After she catches wind of Mrs. Charmond's affair with the married Fitzpiers, she writes to the latter to inform him that his mistress wears a wig. The narrator notes: "It was poor Marty's only card, and she played it, knowing nothing of fashion, and thinking her revelation a fatal one for a lover." 42 Though Fitzpiers is slow to read Marty's correspondence, its effect is the one anticipated by the peasant girl (despite the narrator's scepticism): the physician satirically jeers Charmond following the revelation, resulting in their breakup and Fitzpiers's "abrupt departure" from their elopement on the Continent. However, the implications of this end to Charmond and Fitzpiers's relations have even graver consequences for the former than 
Marty, or indeed anyone, could have possibly expected. Dramatic justice is served brutally, since Charmond, in her attempts to follow Fitzpiers and make amends, is confronted by a former South Carolinian lover and then shot dead after an impassioned argument.

The punishment that Charmond faces for her misdeeds in The Woodlanders is certainly harsher than those facing other discovered prosthesis users in similar plots. Always present in plots in which female prosthesis users are revealed and subsequently rejected is the suggestion that to wear false body parts is indicative of a predilection for fraudulence more generally-a point that supports Jerrold's observations. Implicitly, women who mask their physical differences by using prosthetic body parts might be concealing more than simply non-normative anatomy. They might, for example, be fallen women in disguise, as in the case of Isabelle Vane in Ellen Wood's East Lynne (1860-1861), who is able to masquerade as a governess in her estranged husband's family home by employing the use of blue-tinted spectacles and a veil. ${ }^{43}$ By comparison, Louisa May Alcott's similarly sensational 1866 novella Behind a Mask depicts an actress who uses false hair and teeth to pose as a governess and eventually marry her way into an aristocratic position. ${ }^{44}$

Female prosthesis users were thus in many cases akin to or sometimes literally actresses, who, as Tracy C. Davis notes, remained associated with prostitution and inappropriate sexual conduct. ${ }^{45}$ The link between false body parts and sexual misdirection was certainly present, for instance, in A. M.'s "Was She False?": a short story whose very name implies deception beyond mere material means. Here, Uncle Mortimer's response to discovering that his wife-to-be wears false teeth in this tale is revelatory. Upon discovery, he exclaims: "She's treacherous! I have been deceived all through. I daresay the rest of her is as false as her-but no matter! I am disenchanted at last. I have bidden her an eternal adieu!" 46 To Mortimer, as signified by his inference that "the rest of her" is false and as his inability to complete his sentence, the prosthetic part is a synecdoche of falsity more generally. This view is supported in the 1892 Pick-Me-Up comic article "Women: By Our Office Boy," which (in cockney dialect) critiques what it sees as a fashion for fakery among women: "Look how a woman 'fakes' herself! Paint, powder, false teeth, false hare, and-oh, that I should have to rite it! - a false buzzum, wich, by-the-by, gen'rally covers a false hart!" 47 The same link between what we might call primarily cosmetic prostheses and sexual deviance was forged in the so-called "Pepper and Salt" section of Judy in 1886. A short sketch narrates the consequences 
after a jealous wife discovers another woman's set of false teeth in her husband's pocket. Such a disclosure once again associates female prosthesis use with sexual misconduct. ${ }^{48}$

Responding to rapid developments in prosthetic technologies, the somewhat embellished reportage that this progress received, and the apparent ubiquity of certain forms of prostheses-for example, wigs and dentures - some narratives even imagined scenarios where only after marriage did partners realize that they had wedded prosthesis users. One of the most infamous instances where this scenario plays out occurs in another of Hardy major works, Jude the Obscure (1895). ${ }^{49}$ In this brutal tale of crushed aspirations, one of the main impediments facing the eponymous protagonist in his quest for educational, spiritual, and familial success is the fatal attraction that he develops (and can never quite quash) towards Arabella Donn, the devious daughter of a pig farmer. We learn relatively early on, after Jude and Arabella's hasty nuptials, that one of several layers of deception that Arabella uses to ensnare her husband is an appearance of abundant hair produced by prosthesis use. On the very evening of their marriage, to his disappointment, Jude discovers that Arabella uses chignons (these are false curls of the kind represented visually in Fig. 5.2):

A little chill overspread him at her first unrobing. A long tail of hair, which Arabella wore twisted up in an enormous knob at the back of her head, was deliberately unfastened, stroked out, and hung upon the looking glass which he had bought her.

"What—it wasn't your own?" he said, with a sudden distaste for her. ${ }^{50}$

Jude's reaction—shock, "distaste," and incredulity—is telling of late nineteenth-century responses to false hair, as well as more general standards of women's beauty, which preferred a natural look. But Arabella's response to Jude brings to the fore how social expectations ironically also informed her decision to use prosthetic hair additions. Reacting to Jude's question as to whether the hair is not her own, Arabella explains: "O noit never is nowadays with the better class." To this comment, the clearly riled Jude responds: "Nonsense! Perhaps not in towns. But in the country it is supposed to be different. Besides, you've enough of your own, surely?" But once again, Arabella uses convention to defend herself: "Yes, enough as country notions go. But in towns the men expect more .... The more you have the better in Aldbrickham .... Every lady of position wears false hair-the barber's assistant told me so." ${ }^{51}$ Here, Arabella aligns her 


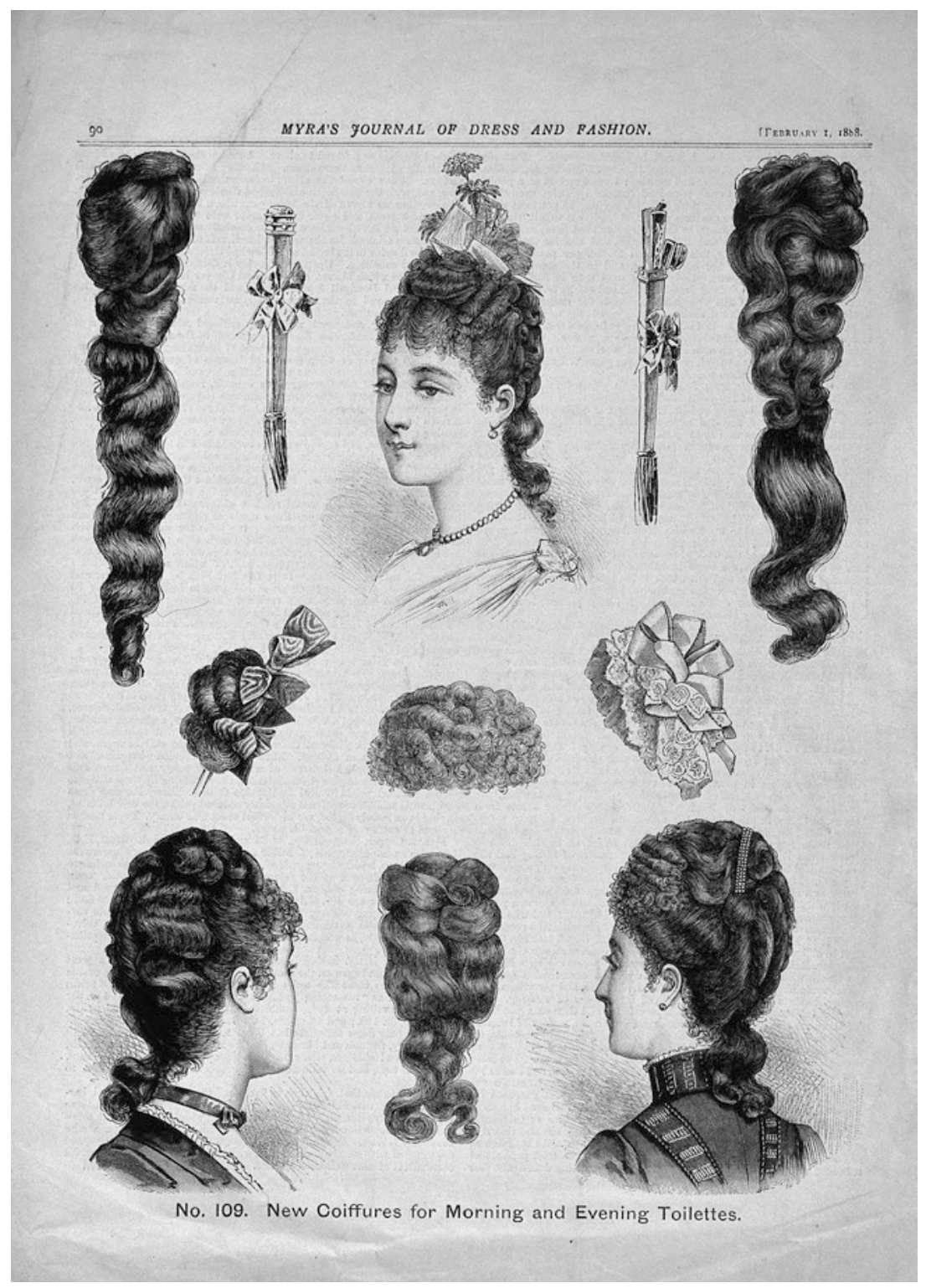

Fig. 5.2 A magazine plate depicting various elaborate chignons, individually and in use on attractive, youthful female users. "New coiffures for morning and evening toilettes," plate 109 to Myra's Journal of Dress and Fashion, February 1, 1888, wood engraving, $26.2 \times 18.6 \mathrm{~cm}$, Wellcome Collection, London. Image courtesy of the Wellcome Collection. https://wellcomecollection.org/works/e8bxupkm. CC BY 4.0 
decision to use chignons with metropolitan middle-class tastes, at once revealing Jude's ignorance of supposedly refined urban sentiments-a factor contributing to his eventual failure as a scholar in Christminister-and asserting her provocative forwardness in dealing with the opposite sex. Her frankness ironically contrasts the effect of her prosthesis use, which she admits to deploying in order to deceitfully attract male suitors.

False hair is also clearly used as synecdoche for Arabella's character in Jude the Obscure: the false part is representative of a fraudulent character. She elsewhere sucks in her cheeks to give an impression of dimples; lies about pregnancy to secure Jude's hand in marriage; and plies him with alcohol, preying on his physical and spiritual weakness, to force him to remarry her. Her final and most repugnant duplicitous act comes after she neglects her duties as Jude's nurse while he is battling severe illness. Returning to her lodgings to check on him, she discovers that he has died but pretends that he is asleep so that she can continue to participate in the festivities of Christminister's "Remembrance games." Though not a disability, the way that Arabella's physical difference (her artificial-hair use) functions as a signifier for character flaws-in this case excessive selfinterest, fraudulence, and a lack of empathy. Arabella's false hair is thus certainly treated negatively - matching the stigma attached to female prosthesis users discussed earlier in this chapter-but at the same time its use is decidedly savvy and in line with metropolitan middle-class bodily expectations, which ironically favoured natural beauty while encouraging women to use hair additions.

Key to Hardy's exploration of wigs and the factors that give rise to their use is the role of the prosthesis maker. Note how the authority that Arabella leans on in her justification of wig use is a "barber's assistant." 52 Though only referred to in passing by Arabella, the inclusion of this figure's statements as an explanation for why chignons are needed underlines the influence that these professionals had on consumers. Arabella's commitment to wig-use and her reference to a barber's assistant to support her case shows her susceptibility to marketing, implying that other aspirational women from her social station might also be vulnerable to these tactics. Contemporary wig makers and barbers, not unlike other kinds of prosthesis makers, used a variety of techniques to entice consumers. British wig makers, including Thomas Elliott and "Professor Brown" used literary components in their advertisements to promise female users "restored youthfulness, beauty and the ability to go unnoticed as incomplete' women." $5^{3}$ With, what is fair to say, a clear degree of scorn, Hardy's work 
implies that such commercial rhetoric was effective among consumers of Arabella's social standing. By using dark humour and elements of the grotesque as representational modes, Jude the Obscure suggests that the trickery underpinning the modern women's ability to assume a perception of beauty when she is in fact by contemporary standards incomplete is an issue that cannot be entirely blamed on the female consumers of prostheses. Assistant barbers, and by extension other professionals associated with the prosthesis trade, are exposed as responsible for fuelling trends that encourage the use of artifice.

Although socially conscious writers such as Hardy were cautious not to pin the blame entirely on women for what was perceived as an insidious growth of artifice as the nineteenth century progressed, it is clear from the examples given thus far that a disproportionate stress in the prosthesismarriage plot was placed on women as supposedly duplicitous consumers of artificial body parts. On the one hand, we might consider the prevalence of female prosthesis users in marriage plots as a symptom of what Margrit Shildrick explains as the positioning of women "vis-à-vis an inaccessible body ideal," one which she also notes is even more difficult to attain for disabled women. ${ }^{54}$ For postmodern feminists such as Shildrick and Sandra Lee Bartky, who utilize a Foucauldian approach to women's bodies, we can consider norms of behaviour that affect women's bodies as examples of "disciplinary power"55: "The reiteration of the technologies of power speak to a body that remains always in a state of pre-resolution, whose boundaries are never secured. Indeed, repetition indicates its own necessary failure to establish any stable body, let along an ideal one."56 Continual references to female prosthesis users whose supposedly flawed bodies ultimately stand in the way of happy marriages highlights on the one hand the disciplinary pressures that women faced to conform to normative bodily standards. But the repetition of the trope also speaks to a failure to establish bodily order amid a society that not only demanded physically normative women but also did not fully tolerate the use of devices designed to facilitate an impression of such.

By further emphasizing the instability of prostheticizing as a disciplinary act for incomplete women, female prosthesis users, however, were not always entirely negatively construed in romantic contexts-even when they were packaged in a discriminatory manner. For example, the racing journalist Joe Capp's humorous poem "Rewination!" describes a situation in which a man entices his wife to bed only to discover that she uses a range of prostheses: 
"Oh, come to my arms," said he, said he;

"Oh come to my arms," said he.

And she came to his arms with all her charms,

False hair, false teeth, false calves, false arms,

Yes, she came to his arms, came she.

"Now, let us retire," said he, said he;

"Now let us retire," said he.

Then she placed her false teeth in the water so clear

Unstripped her false arm, and took off an ear.

Lay back in her chair as if for a rest,

Began once again by removing her chest,

While her husband in horror looked on.

"I see you have sold me, old lady," said he.

"I see you have sold me," he said.

"But please tell me now, you deceitful old she,

How much of you is coming to bed,

How much of you is coming to bed." 57

The husband in this poem looks on "in horror" during the undressing scene and addresses his wife as a "deceitful old she," conforming to the views of earlier Victorians. The poem also clearly draws from similar scenes depicted in earlier literary writings, such as Jonathan Swift's 1734 poem "A Beautiful Young Nymph Going to Bed." 58 The title "Rewination!" suggests that the husband has been ruined by the discovery of his partner's artificiality. But the poem is not entirely stable in its treatment of prostheses. In the final two lines, we see how little the husband is deterred. He asks jestingly_perhaps even flirtatiously-how much of his wife is coming to bed, but he does not flee or retract his proposition. In fact, he repeats it twice, emphasizing his hardly wavering sexual desire. In this context, the prosthesis user is stigmatized but ultimately not diminished sexually or cast off socially. As I show later, other Victorian narratives imagined both male and female prosthesis users as not only tolerable but sometimes desirable in romantic relationships.

\section{Marriageable Men?}

Though female users tended to be the focus of prosthesis narratives of failed marriages, some did represent male prosthesis users whose relationships end due to the response of their partners to their physical difference. 
For instance, the 1893 Hearth and Home article "Good Advice and a Wooden Leg," which was initialled "G. W. C.," used an anecdote about a man with a wooden leg to make a point about the virtues of giving out advice. In this somewhat bizarre piece, the writer, who we assume is male, tells a story about a consumptive friend of his whom he advised to go and live on the slopes of the Rocky Mountains, "in the pine woods, in a hut or tent," until "dead or well." The writer describes how he bumped into the same friend several years later, only to be shunned by him after the friend blamed him for the loss of his leg, which we learn was injured by a grizzly bear. This injury, compounded with the fitting of a wooden leg, had dire consequences for the once-consumptive man: though cured of the disease, his fiancée broke off their engagement as she "don't want a husband with a wooden leg." ${ }^{59}$ What is curious about this case is the blame that is attached to the wooden leg rather than the limb loss itself. On the one hand, we might understand the "wooden leg" as functioning as a linguistic supplement for a "missing leg," with its linguistic usage paralleling its use in "real life" as a substitute for an absent part. On the other hand, we might take this phrasing to imply that there is something particularly offputting about a wooden leg, perhaps suggesting its unsettling uncanniness or uncouth physical appearance. A key factor to consider is the readership for this piece, which we see in the subtitle: An Illustrated Weekly Journal for Gentlewomen. The price per issue is also relevant: $3 \mathrm{~d}$. The affluent women that this publication was aimed at would have no doubt agreed with the requirements described by Oliver Wendell Holmes for limbs "which shall be presentable in polite society." What is inferred by the description "wooden leg" is a slight on the primitive design of the chosen device and what such a choice supposedly reveals about the affluence, social standing, and/or taste of its user. If the device is not a limb "which shall be presentable in polite society," then to a gentlewomen reader neither is its user. ${ }^{60}$

We learn from another fin-de-siècle short story, André de Blaumont's "My Fiancé's Glass Eye," that related prejudices surrounded male glasseye users. Published in Alfred Ludlow White's Short Stories: A Magazine of Select Fiction (1894) and then in the Massachusetts pro-Catholic newspaper The Sacred Heart Review under the variant spelling "Andree de Beaumont" in 1895, the light-hearted domestic narrative tells the story of an engagement that is almost broken off after the wife-to-be is mistakenly led to believe that her betrothed is a glass-eye user. ${ }^{61}$ Written from the perspective of the man's fiancée, Angela, early on the story describes her 
potential husband, Raoul, in glowing terms. The opening lines read: "He was tall and dark, to my eyes charming in every respect." Angela's devotion to Raoul is exemplified as she decides to reveal to him all of her "faults" as, being an honest woman, she feels that it is best if they are known before they are married - a tactic that clearly contrasts with those of several of the prosthesis users described so far. Following this revelation, Angela asks what Raoul's faults are, at which point he becomes embarrassed and says nothing. We then learn that he is short-sighted and uses a monocle. Soon after this discussion, Raoul departs to get his affairs in order so that he can marry his beloved. Shortly after his departure, the housemaid, Justine, brings Angela and her mother the shocking news that Raoul has left behind his "glass eye." The responses of Angela and her mother are telling: Angela initially bursts into tears: "Mamma, mamma! He has a glass eye, it is frightful! I shall never get over it! I shall die of mortification!" Her mother, with an air of self-assurance, consoles her: "This gentleman has deceived us, that is all. To tell the truth, I always found something strange in his looks." Angela's mortification soon turns to tenderness, however, once she imagines that Raoul most likely lost his eye "in some honourable, noble way" and feels that she still loves him "even with his one eye." Her mother's stance is somewhat more hard-line. Responding to her daughter's quick change of heart, she asks,

Are you crazy? Can you imagine for a moment that I would permit you to marry a man with such an infirmity? As pretty as you are, and only nineteen! No, a thousand time no, my child, so do not create a romance of devotion and sacrifice, for it is useless. I would never consent to your marrying a oneeyed man. Why, if he should lose the other eye he would be blind! How pleasant that would be! ${ }^{62}$

Fortunately, the dispute does not escalate further, despite Angela's assertion that she "would be his faithful dog, to lead him about and protect him"-a statement that indicates the respect with which the canine companions of the vision-impaired were sometimes treated in the Victorian imagination. ${ }^{63}$ When Justine presents Raoul's "glass eye" to Angela, it becomes apparent that the house servant confused the man's monocle with an ocular prosthesis. ${ }^{64}$

Regarding the use of prostheses in marriage plots, this short story reveals several relevant points. First, the narrative makes apparent the 
instability of attitudes towards male prosthesis users in terms of marital potential. The conflicting views that Angela and her mother express suggest that there is more to the issue than simply the view that using a prosthetic device disqualified a man from the marriage market. There is certainly a considerable level of revulsion expressed towards the prospect of Raoul being a glass-eye user, and, like female prosthesis users, he is accused of deceit. But Angela is also quick to forgive him, guessing that he injured his eye performing a noble deed. Though Raoul is affected by some of the same stigma that the female prosthesis users above suffer, more leeway is provided to the assumed male prosthesis user. While little to no attention is paid to the causes of prosthesis use for female users in the stories above, leaving it to the Victorian reader's imagination to assume what was seen as the worst-that their physical losses are congenital and thereby potentially heritable-the narrator's concern with this issue implies that there were preferable causes for physical losses among men. These causes could mitigate concerns regarding marrying a physically incomplete man. As David Serlin has observed, since the American Civil War prostheses and other visual markings that proved injury became "visual shorthand for military service." "Disability," Serlin remarks, "became the permanent uniform worn by those who participated in the aftermath of civil warfare." ${ }^{65}$ Literary works, such as Charlotte Brontë's Jane Eyre (1847), also depict injuries including limb loss and blindness as potential markers of noble or redemptive deeds. Rochester sustains these injuries while attempting to rescue his estranged wife from the house fire that she started ${ }^{66} \mathrm{~A}$ gendered double standard for prosthesis use is brought to the fore by "My Fiancé's Glass Eye": respect or honour might be hastily bestowed on some men with acquired body losses, maintaining their status as eligible bachelors, but women with similar physical differences were rarely treated in this way.

There is a further aspect of Justine's misrecognition of a prosthetic eye. On the one hand, we can say that de Blaumont/Beaumont's narrative uses female working-class ignorance as a narrative and comic prop: Justine's confusion of a monocle with a glass eye drives the story and brings comic relief once her mistake has been made apparent. But on the other hand, in an illuminating manner, the story draws our attention to the understandable lack of knowledge that working-class women might have regarding sophisticated prosthetic technologies. Justine's confusion certainly brings to the fore semantic questions. What constitutes a prosthesis? Is a monocle 
not in fact a kind of glass eye? But de Blaumont/Beaumont's story also hints at the inaccessibility of prostheses to the contemporary working classes. Artificial eyes were sold to surgeons for \$10 in New York-based John Reynders \& Co.'s 1889 Illustrated Catalogue and Price List of Surgical Instruments-a price relative to the "income value" of $\$ 2890 / £ 2258$ in 2019. ${ }^{67}$ Charles Lenz \& Sons of Philadelphia offered a rather improved price of $\$ 5$ circa 1892 , but this still represented a high commodity price-a price relative to the "income value" of $\$ 1300 / £ 1016$ in 2019.68 In 1893, Charles Traux, Greene \& Co offered artificial eyes from the "Finest French and German Manufacturers" for the trade price of $\$ 3.50$ each or directly to patients for $\$ 10$ each-prices relative to the "income value" of $\$ 989 / £ 773$ and $\$ 2830 / £ 2211$ respectively in 2019. ${ }^{69}$ On the other side of the Atlantic, the Down Bros. of London sold artificial eyes made to order for $£ 11 \mathrm{~s}$. in their 1890 catalogue-relative to the "income value" of $£ 817 / \$ 1046$ in $2019 .{ }^{70}$ Given the average hourly compensation for unskilled work in America was $\$ 0.14$ in 1894 , and that in the same year average annual nominal earnings in Britain were just short of $£ 62,{ }^{71}$ one can begin to see from an economic standpoint why a servant might not have been familiar with these devices if their master or mistress did not use them: when one considers the added profit margin of the surgeon or ophthalmologist selling the device on top of all but one of the prices provided above, we can conclude that purchasing an artificial eye would have involved a considerable outlay for someone in Justine's position.

Monocles, meanwhile, were, as Richard Corson notes, often used as "a matter of fashion in imitation of the aristocracy." 72 Marius Hentea observes how ubiquitous these devices were among the intelligentsia during the period of high modernism in the early twentieth century. ${ }^{73}$ House servants, such as Justine, it is clear, both economically and socially speaking, fell far outside the target social market for both monocles and glass eyes, in part making Justine's ignorance in this narrative an entirely plausible representation. One also should consider the fact that if you had good eyesight and were not missing an eye-as seems to be the case with Justine-there might be very little reason for one to know the differences between eyeglasses and glass eyes, especially given the pressing concerns facing individuals in her social position, including stark economic realities and long working hours. 


\section{"Love Which Conquers All Reversals and Disabilities"}

The scandal in "My Fiancé's Glass Eye" in the end proves to be much ado about nothing since the misrecognition of the monocle as a glass eye becomes clear. But regarding gender, the story implies that if a gentleman's social position might not be adversely affected by his use of an ocular prosthesis - in other words, if it might be "presentable in polite society" and not a barrier to work- then it might be tolerated by a female suitor. We also learn that prosthesis use might be accepted romantically speaking, if the injuries leading to its use were sustained performing noble deeds. In the way that it engaged with themes of devotion and tolerance, de Blaumont/Beaumont's story draws from the sentimental mode, which often deploys the motif of "love which conquers all reversals and disabilities." ${ }^{74}$ Earlier in the century, on the other side of Atlantic, Charles Dickens drew from and tested the limits of this trope in his 1840s novels Barnaby Rudge (1840-1841) and Dombey and Son (1846-1848). ${ }^{75}$ In these works, Dickens depicts circumstances in which men are made more attractive by their physical differences and/or prosthesis use. In Barnaby Rudge, a novel set in the late eighteenth century, the son of an inn keeper, Joe Willet, only manages to secure the heart of the woman he has long admired, Dolly Varden, after he loses an arm fighting for the British against American revolutionaries. Indeed, though the once coquettish Varden rejects Joe's advances before his departure to America, his return injured stimulates the development of both warm sentiments and emotional maturity in Dolly.

Less conventionally, and more relevant to the literary history of prostheses, Captain Cuttle of Dickens's slightly later novel Dombey and Son is another amputee male who is depicted as romantically attractive. Though his prosthesis use (he has a hand with interchangeable heads) is not directly described or implied as an enticing feature, the pursuit of him by his landlady, the widow Mrs. MacStinger, a figure as fierce and intimidating as her surname would suggest, is one of the main comical threads in Dickens's novel. In this regard, the novel riffs off the prosthesis-marriage plot trope. Dickens uses an extended metaphor of naval battle to describe the somewhat odd and one-sided romantic subplot connecting Cuttle and MacStinger: the widow is "the enemy" from whom the Captain, with the help of his allies, attempts to avoid "discovery and capture." the typical prosthesis-marriage plot, in which either a physically normative male mistakenly pursues a female prosthesis user or a prosthesis-using 
male hopelessly courts a bodily normative female, here a seemingly nondisabled female goes after a man whose prosthesis use is conspicuous. Cuttle's prosthesis is in fact a defining feature according to Dickens's narrator. Cuttle is first introduced as "a gentleman in a wide suit of blue, with a hook instead of a hand attached to his right wrist," 77 and the device is in regular use throughout the novel. For example, he arranges his hair with $\mathrm{it}^{78}$; he replaces the hook with a knife attachment and peels with it $^{79}$; and he exercises "great power" over young boys with it. ${ }^{80}$ Though not present when Cuttle performs many of these actions-because he spends most of the novel hiding from her-MacStinger is not in the least deterred by the Captain's use of a replaceable hook hand. In fact, after he escapes his lodgings at her home-thanks to the assistance of his apprentice, Rob the Grinder-her pursuit of him, though we do not witness it as readers, is described as relentless. First, we learn that MacStinger would "never hear of his deserting" her and her children, leading Cuttle to the "desperate determination of running away." After his escape, Cuttle appears to be "too well acquainted with the determined and dauntless character of Mrs. MacStinger, to doubt that that heroic woman had devoted herself to the task of his discovery and capture." ${ }^{\prime 1}$

Cuttle's worst fears are actualized when, assisted by her children, MacStinger eventually finds and accosts him at the Midshipman, his new home, which he shares with the nautical instrument maker Solomon Gills. ${ }^{82}$ Thankfully for Cuttle, he is rescued by his friend and fellow skipper Captain Bunsby, who consoles MacStinger, takes her home, and, as we later learn, is ensnared into marrying her. Curiously, like Cuttle, Bunsby displays physical difference: he is described as a "bulk-head-human, and very large-with one stationary eye in the mahogany face, and one revolving one, on the principle of some lighthouses." ${ }^{83}$ Bunsby is slightly later described "to be always on the look-out for something in the extremest distance, and to have no ocular knowledge of anything within ten miles." 84 Certainly Bunsby is a good fit for the nautical theme that Dickens develops in the novel-his fixed eye resembles a telescope, always looking into the distance, and his revolving eye takes after a compass, moving and adjusting in chaotic scenarios to identify the right course-but we could also read him as a possible artificial-eye user due to the signifiers provided: one of his eyes is stationary and carries a permanent expression as though it is looking into the far distance-for instance, when Cuttle talks to him in Chapter 39, his eye "look[ed] fixedly at the coast of Greenland." These 
descriptions align with Jerrold's description of how artificial-eye users appeared prior to the advent of Auguste Boissonneau's enamel eyes, which first came to Britain in the early 1850s: "While one eye was gazing intently in your face, the other was fixed in another direction-immovable, the more hideous because at first you mistook it for a natural eye. A smile may overspread the face, animate the lip, and lighten up the natural eye; but there was the glass eye-fixed, lustreless, and dead." ${ }^{85}$ Bunsby's depiction fits this description, though Dickens never explicitly states whether he is an ocular-prosthesis user. Either way, it is intriguing that MacStinger's affections are displaced from a hook-hand user onto a figure whose physical difference is also manifest. It is implied, therefore, that MacStinger is either not deterred by or perhaps even directly attracted to men whose bodies would have been considered contemporaneously as non-normative.

A key concern for MacStinger appears to be the care of her loving but somewhat unruly children, for whom Cuttle claims to have done "a world of good turns." ${ }^{86}$ Her attraction to physically different men might thus be partially explained by her apparent belief in the potential of these men for excelling in the line of domestic work. Because they are neither youthful nor physically whole, they appear, by contemporary standards, no longer suitable for the labour market, therefore making them, in the eyes of MacStinger, available for work within the home. As implied by the "great power" that Cuttle is said to exercise over MacStinger's young boys with his hook, the physical differences of these Captains make them, for MacStinger, uniquely suited to childcare. ${ }^{87}$ In this regard, we might consider this depiction as exemplifying Schaffer's argument about depictions of "familiar marriages" in Victorian literature: "instead of feeling erotic desire for another's body, familiar marriage advocates sympathetic helpfulness; instead of demanding a private dyad, familiar marriage wants a larger social network; instead of valorizing the self-made man, familiar marriage prizes unselfish participation in a system of mutual care." ${ }^{\prime 88}$ In the case of Dombey and Son, we see that Cuttle and later Bunsby offer opportunities to MacStinger that will enlarge her social network and enhance the lives of her children in return for other forms of care-cooking, cleaning, and so on. Dickens, though, hardly sets up this form of marriage as an exemplary model. Both Cuttle and Bunsby fear MacStinger and they appear resistant to the kind of life that a union with her presents. They both describe such an arrangement in humorous terms as "capter." 89 Though I am resistant 
to interpreting Cuttle's prosthesis use as symbolic of "castration," as John Jordan suggests, it is clear that this language of imprisonment implies fear regarding the believed emasculation that figures like Cuttle and Bunsby might experience if faced with a life of domestic servitude. ${ }^{90}$

\section{Enticing Devices}

While Dickens experimented with the idea that amputees might appear attractive to women in certain social positions due to the potential that they offer in extending social networks, in other writings prostheses were represented as attractive because of the economic status that they signified. One narrative that imagined a prosthetic body part as an attractive feature on a male user was Geoffry Brandon's 1899 short story "The Story of the Jewel in the Stage Coach as Related by Simon Simple Barristerat-Law." 91 The piece was published in the Ludgate, an illustrated family magazine, which was a less-successful competitor to the Strand Magazine - a title made popular in the 1890s through to the 1920s thanks largely to the success of Arthur Conan Doyle's Sherlock Holmes short stories. Brandon's narrative tells the story of a relationship between a daughter of a lawyer and a gentleman that begins with an odd first encounter: the spinster Mistress Kesia Clawby attempts to grab what she believes to be a jewel resting on the back seat of a dark London coach, only to find that the glimmering object is in fact the glass eye of a small man, who we later discover to be a judge, Sir Benjamin Cossett. Not knowing that Mistress Kesia is the woman who "assaulted" him on the coach, Sir Benjamin warms to the lawyer's daughter at a later soirée. The narrator notes that Mistress Kesia "was certainly not a 'giddy flirt." Witnessing this relationship kindling, the first-person narrator cynically notes: "I perceived what sort of card the good lady was playing, and that she meant to own that jewel of a glass eye after all." Mistress Kesia and Sir Benjamin go on to marry, emphasizing how little the former was deterred by the latter's use of a prosthesis, which is even said to look "fishy" following the poke administered on the coach. ${ }^{92}$

Brandon's story is not dissimilar to the Cheshire Observer's 1879 comic sketch "He Fixed Her with His Glassy Eye," in which a man uses his glass eye as a prop to woo a woman whom he finds attractive. When asked why he is staring at her, he returns: "It's a glass eye madam-only a glass eye. But I'm not surprised that even a glass eye should feel interested in so pretty a woman." 93 Unlike this sketch, though, in which the prosthetic 
body part serves an advantageous rhetorical purpose, in Brandon's short story, rather than being an undesirable physical feature, Sir Benjamin's jewel-like glass eye is a signifier of wealth and prosperity. We can see from the relatively high contemporary cost of ocular prostheses stated earlier $(£ 11 \mathrm{~s}$. for medical practitioners in Britain in 1890) that one would need to be reasonably wealthy to consider purchasing such a device. Given that average annual nominal earnings were $£ 56$ 10s. $1 \mathrm{~d}$. in 1890 , we can surmise that ocular-prosthesis use was a fairly consistent indicator of prosperity. ${ }^{94}$ In this social context, a high-end prosthesis, rather than detracting from a man's attractiveness, might signify wealth and social status, arguably the two most important qualities for men to exude within the contemporary marriage market.

As Vanessa Warne shows, however, female prosthesis users were also imagined as attractive partners for financial reasons in certain Victorian literary works. Warne draws our attention to Hood's poem Miss Kilmansegg and Her Precious Leg and Smith's short story "The Lucky Leg," arguing that "[b]oth texts ... deal with the logic of attraction: the marriage of an able-bodied man to a disabled woman involves either the acquisition of new wealth or the preservation of already inherited wealth." 95 At the centre of Hood's poem is a marriage plot involving the affluent eponymous protagonist who, following a riding accident that results in the amputation of her right leg, demands a prosthesis made of solid gold. As we have seen in Chap. 3 , she is courted by and eventually marries an Italian Count, who later murders her using "Her Precious Leg" so that he can have it melted down and used to service his considerable gambling debts. Smith's slightly more positive depiction, on the other hand, tells the story of the workingclass amputee Mary Wigley who is mysteriously courted and later married by an affluent man, named Mr. Gordon. As the mystery behind Gordon's "peculiar interest" is revealed, we learn that he had two previous wives, whom had both died. Both women were wooden-leg users, and the first left her estate to Gordon on the condition that he married another amputee. Warne is understandably more positive about Smith's story, but she cautions against reading either as particularly progressive. Regarding Hood's poem, she notes that it "complicates the conventional association of disability with dependency" and seems somewhat progressive in the way that Miss Kilmansegg chooses to use an obviously artificial device, resisting the mandate to pass as normal. However, as she goes on to explain, "It is ... difficult to read the poem in general as progressive. Miss Kilmansegg is unembarrassed by her disability, because her loss of a leg allows her to 
control a large portion of her family's wealth. It also provides her with a means of displaying this wealth." ${ }^{96}$ Of course, also problematic is the way that Miss Kilmansegg is killed off as a kind of heavy-handed, moralistic punishment for her ostentation. By comparison, Smith's story is somewhat different in terms of class politics as it traces the social rise of an amputee, who is seemingly rewarded for acting virtuously as a female amputee. She keeps her physical difference discreet and even allows her guardian to write to Mr. Gordon to inform him of her disability after it is feared that he has overlooked the fact. But clearly this depiction is heavily influenced by conservative attitudes regarding physical difference. Though the story ends with the provocative question "who knows all of the advantages of disadvantages?" Smith depicts Wigley's successful fate as the result of a combination of rare favourable circumstances and behaviour underpinned by bodily normative and patriarchal values: Mary makes every attempt to conceal her difference, is honest when called upon, and is largely passive throughout the story. ${ }^{97}$ As we will see later, however, other writings from this period imagined prosthesis users as attractive for less fortuitous and more radical reasons.

\section{Prosthetic Matches}

As I have demonstrated here, prosthesis-marriage plots were sometimes represented as primarily economic exchanges, a trope that was transgressive in the way that it resisted positioning those with physical differences as dependents but ultimately not entirely progressive in terms of depicting them as attractive in other ways. Another romantic plot structure that was radical in some ways but also tainted by conservatism was that which represented prosthesis users marrying each other. The results of such a scenario were depicted in the 1819 etching Il faut des epoux assortis Dans les liens du Mariage [Persons in Wedlock Should Be Properly Matched] (see Fig. 5.3), which shows a couple displaying the various prostheses that they use, including artificial buttocks, breasts, hair, eyes, and teeth. Similarly, in the New Monthly Magazine/New York Monthly Magazine M. Sullivan's serialized novel Stronger than Death, we see that "two ineligible candidates for marriage," a woman with a glass eye and a man with a wooden leg, are united in wedlock. ${ }^{98}$

A further prosthesis marriage plot, which was popular in both nineteenth-century Britain and America, which utilized a similar trope, was Heinrich Zschokke's short story "Das Bein"-first published in the 


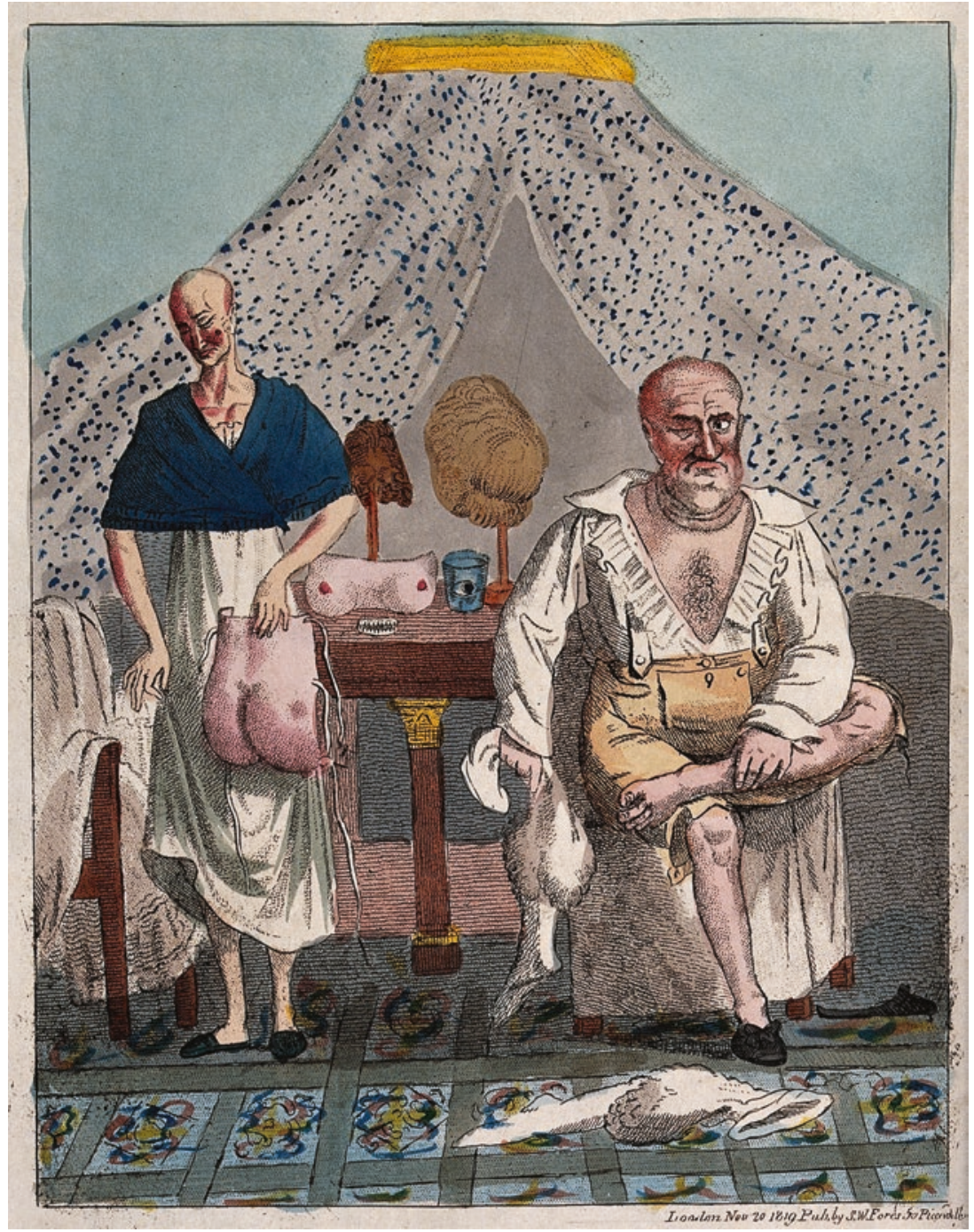

Fig. 5.3 An early nineteenth-century coloured etching that portrays a couple underdressing, removing their various prostheses, which include artificial buttocks, breasts, hair, eyes, and teeth. Il faut des epoux assortis Dans les liens $d u$ Mariage, 1819, etching, $25 \times 19.2 \mathrm{~cm}$, Wellcome Collection, London. Image courtesy of the Wellcome Collection. https://wellcomecollection.org/works/ fwk3ub5b. CC BY 4.0 
German monthly magazine Erheiterungen in $1811 .{ }^{99}$ Zschokke's narrative appeared in Britain in the Kaleidoscope in 1827 and was subsequently reprinted - often without acknowledgement of its original author or translator-at least fifteen times in British newspapers and periodicals and twenty-nine times in the American press between 1827 and 1906. ${ }^{100}$ These reprintings appeared under various titles, including "The Leg," "Was He a Madman?" "Losing a Leg to Gain a Wife," "Love's Amputation; or, A Leg for a Lady," "Giving a Limb for a Wife, with Future Regrets," and "A Case in Surgery. Which Shows That a Man May Do Too Much for Love of Woman." 101 Under its various guises, this somewhat misogynist tale narrates the French surgeon Lewis Thevenet's encounter with the Englishman Charles Temple. The latter travels to Calais, has the surgeon collected from his home by carriage, and then tries to convince him to amputate his right, uninjured and unimpaired, leg. At first, Thevenet outright rejects Temple's demand, maintaining his stance even when the latter points a pistol at him. But the surgeon later resigns himself to performing the operation to spare Temple additional suffering after the Englishman turns the gun on himself, threatening to shoot his own leg to necessitate the procedure. We later learn from a letter of thanks sent to Thevenet by Temple that the latter demanded the amputation so that he could marry the woman he loved, a fellow amputee who rejected his first marriage proposal when he had two legs. As Temple explains: "Miss Harley was a wonder of beauty, but she had but one leg. [O]n account of this imperfection she feared to become my wife lest I should esteem her the less for it." Here, the burden of social attitudes to physical difference initially proves an obstacle to romantic relations, though a second amputation becomes a catalyst. In the same letter, Temple recites how Miss Harley was the first person that he visited after returning to England as an amputee, and that the two were married shortly thereafter. He even entrusts to her the sacrifice that he made after marriage and he claims that "She loves me now the more affectionately." Still, as Thevenet predicts, Temple comes to regret his sacrifice. When the two men meet in England some years afterwards (Thevenet flees France during the Revolution), Temple reveals that his marriage did not work out. He explains: "her wooden leg prevented her dancing, so she betook herself to cards and to fashions. There is no such thing as living peaceably with her." Reflecting on his physical sacrifice, he tells Thevenet, "It was a silly adventure. Had I my leg again, I would not give the paring of a nail. Between you and me, I was a FOOL." 102 
The extent to which the narrative appears progressive in its treatment of amputees as marriageable is compromised by its conservative conclusion, which reinstates the physically whole body as sacrosanct. Though the attraction towards an amputee woman is shown to be so strong that a nondisabled male willingly has a leg amputated to better his chances of marrying her, such a sacrifice is shown to be foolish when we learn of the unhappy outcome of their matrimony. To use disability-studies scholar Michael Oliver's language, the story ultimately conforms to a view of disability as a "personal tragedy." 103 It provides historical evidence for Alison Kafer's observations about how ableism affects imaginings of disabled futurity: "If disability is conceptualized as a terrible unending tragedy, then any future that includes disability can only be a future to avoid." 104 The narrative also draws attention to the physical and social drawbacks of Temple's decision, further reinforcing the hegemony of wholeness: Temple can barely stand up when reunited with Thevenet and notes himself that his "cursed leg" is a "hindrance to [him] in everything"; he also observes that he would have "been an admiral of the blue [a squadron of the Royal Navy], had not [his] wooden leg disqualified [him] from the service of [his] country." ${ }^{105}$ Here, though his wooden leg was represented initially as a catalyst to marriage, it is ultimately depicted as an obstacle, which not only brings him unhappiness and physical difficulties, but also emasculates him by removing him from the social arena of work.

Zschokke's conclusion aligns the stories about other cultural representations of prostheses, which satirize the sacrifices that certain women expected their partners to make for them. For instance, the wood engraving shown in Fig. 5.4 depicts a couple passing by the window display of an "oculariste" (glass-eye maker). Clearly responding to the popularity of the artificial eyes produced by Parisian prosthetist Auguste Boissonneau, who coined the term "oculariste," the woman tells her blue-eyed lover that the man of her dreams has black eyes and asks if he could obtain artificial eyes to remedy this discrepancy. Sources like this one show how, within romantic plots, prostheses were both the targets of and the tools used for misogynist satires involving women with marital aspirations.

\section{Countering Concealment}

While prosthesis users were most often framed as eligible in marriage plots owing to financial reasons, out of sympathy, because their prospective partners were also physically different, or because of the social prospects 


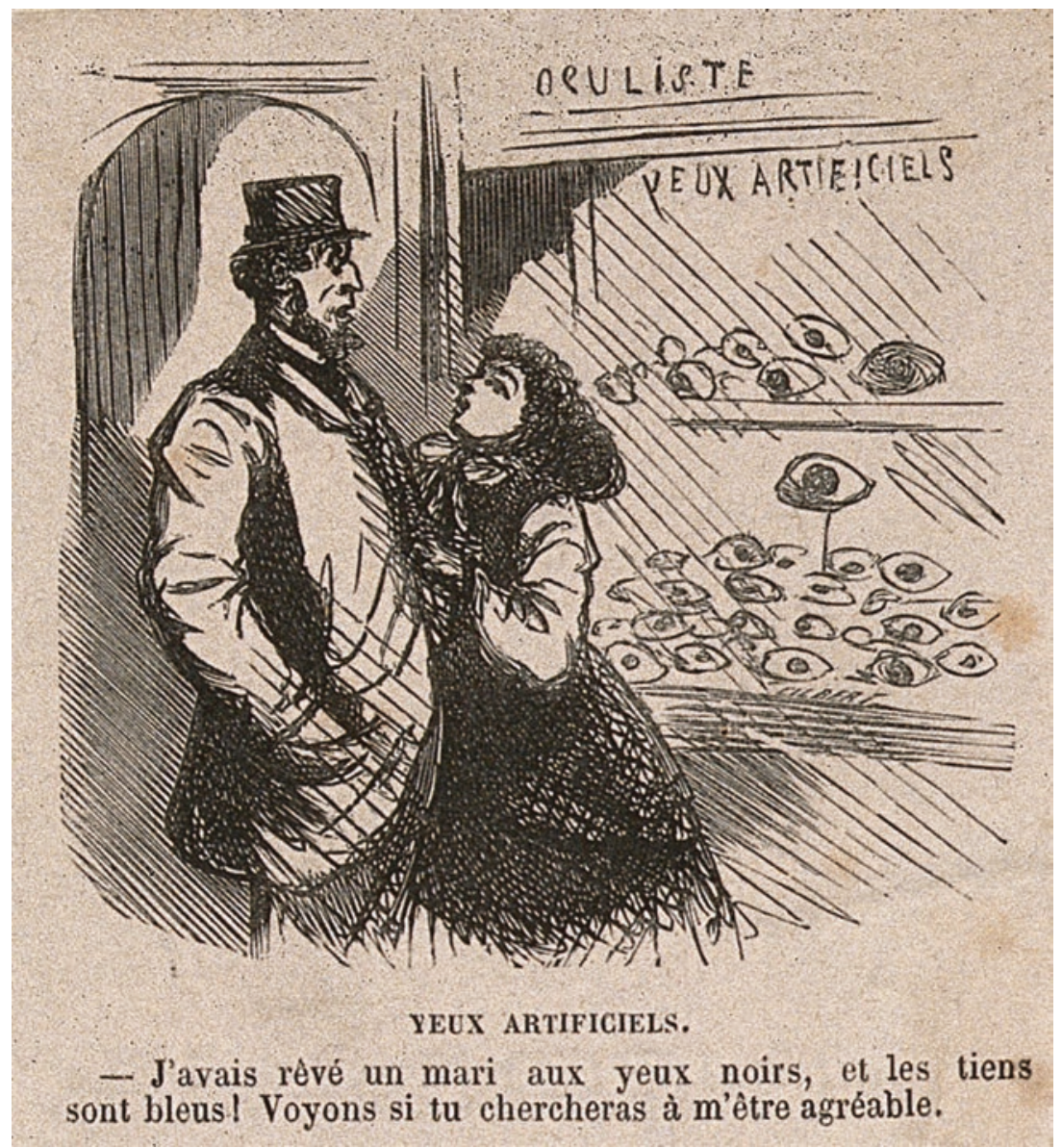

Fig. 5.4 A mid-century wood engraving, which mocked the supposedly outrageous demands that young women made of their partners. Here a couple pass by an ocularist's window and the woman asks her partner whether he would consider changing his eyes to darker ones. Yeux Artificiels, c. 1868, wood engraving, Wellcome Collection, London. Image courtesy of the Wellcome Collection. https://wellcomecollection.org/works/eu4hegsx. CC BY 4.0

that a marriage with them offered, on rare occasions prosthesis use was framed as an attractive feature in its own right. Arguably, the most radical nineteenth-century prosthesis marriage plot was Robert Williams 
Buchanan's 1862 Temple Bar short story "Lady Letitia's Lilliput Hand." In this final section, I show that Buchanan's narrative presents a prosthesis user whose transgressive marital success stems from her eventual decision to embrace rather than conceal her physical difference.

Buchanan's "Lady Letitia's Lilliput Hand" was written in the style of sensation fiction and published when that literary mode was at its height in 1862. It therefore appeared almost a decade before the author's careerdefining public spat with Algernon Charles Swinburne and Dante Gabriel Rossetti, in which he infamously claimed that these Pre-Raphaelite poets belong to a "fleshly school of poetry" - a charge that seems somewhat rich after learning more about Buchanan's earlier short story. ${ }^{106}$ "Lady Letitia's Lilliput Hand" explores the history of an alluring yet highly mysterious woman whose most attractive features are her conspicuously dainty, perfectly formed hands. As the narrator remarks, "it was by her beautiful hands that the Lady Letitia achieved her choicest triumphs. Hands so tinily, delicately lovely were never imitated by sculptor; and when she waved them before her slaves, the heart was hushed with admiration." 107 Helena Michie has identified how common it was for women's hands to function as sexual symbols in the Victorian novel. ${ }^{108}$ As Clare Stainthorp puts it: "Nineteenth-century norms of female dress pushed the localisation of the erotic to the peripheries of the body, the hand being one such site." 109 But in the case of Lady's Letitia, the narrator's "normative positivism" (in this case, his idolization of the physically normative female form) is complicated once we learn more about one of her hands in particular. ${ }^{110}$

We first meet Lady Letitia amid a scramble of suitors attempting to wed her. The frontrunner for her affections, the wealthy artist Edward Vansittart, is kept away by the protagonist after a second mysterious character, Mr. Montague Vernon, appears on the scene. As we move forward, we learn that this new arrival is a disguised figure from Lady Letitia's past. Vernon is, in fact, Louis Carr, the once fraudulent associate of her late husband, the financially ruined gambling addict Lord Augustus Marlowe. The narrator reveals that Vernon/Carr had previously attempted to win Letitia's affections by manipulative and duplicitous means and intends to do so again by blackmailing her with misleading evidence that portrays her as Lord Augustus's murderer. The visual motif that Buchanan centres on when the unravelling mystery is Lady Letitia's wonderfully formed left hand, which we learn is prosthetic. The narrator reveals that her hand was amputated after it was crushed by a heavy window during a deathbed 
struggle with her late husband, who had poisoned himself to frame Lady Letitia as his murderer, a desperate attempt at revenge after discovering that Carr's attempts to woo his wife had made progress. All ends well, however. Lady Letitia manages to counter Vernon/Carr's blackmail by threatening to claim him as an accomplice and reveal his identity to the authorities - a move that would be disastrous for the blackmailer since he is wanted for gambling fraud. Carr flees but is unluckily arrested and later hanged for his crimes, while Lady Letitia and Vansittart are happily reunited. Running counter to contemporary marital norms, Vansittart marries Lady Letitia even after she reveals all, including the fact that her most prized asset, her hand, is artificial. As a kind of postscript for the narrative, the narrator includes a note from Vansittart commenting on his marriage with Lady Letitia. We learn that she was a great wife and that she died after giving birth to his eldest daughter. Underlining the narrative and symbolic work that the prosthetic body part does in this story, it ends with a Gothic yet sentimentalized image: Vansittart reveals that he keeps "the Lilliput hand" as "a memento." 111

Buchanan's short story draws special attention to the sensory difference of Lady Letitia's prosthesis. The bodily variation that her hand presents is a source of mystery, intrigue, and grotesqueness. Her hand is cold to touch, providing a grotesque morbidity as well as a sense of foreboding and uncanniness to her literary depiction. The coldness of her hand provides a hint of her non-normativity, echoing the concern of the British prosthesis maker Henry Heather Bigg, who in 1855 lamented the fact that "touch instantly decides between the real hand and its counterfeit." 112 Adding to the grotesqueness of Buchanan's depiction, there is a shocking scene in which her hand is stabbed right the way through without causing so much as a drop of blood or cry of pain. Her hand is thus presented as conspicuously different to an organic one in that it both feels nonnormative and is unable to feel itself. The that her hand is prosthetic exacerbates the tension between her passive, touched, aristocratic, feminine hand and the active, touching, middle-class, masculine hands of her suitors. ${ }^{113}$ In aesthetic terms, the hand acts as a Gothic motif, a kind of uncanny vestige of the past that works as a sensational plot device. We could also label the stabbing scene as an instance of "bodily shock," a trademark of the sensation-fiction genre. The centrality of Lady Letitia's prosthetic hand to nexus of the plot provides evidence for Martha Stoddard Holmes's and Mark Mossman's argument that "[d]isability can be seen as central to the very poetics of sensation fiction." 114 However, there is clearly embedded in Buchanan's narrative a comment on the pressures of 
normativity. Though underpinned by a way of thinking about the body that privileges organic physical completeness, the haptic critique of the prosthetic that this story brings to the fore questions the efficacy and potential implications of using a hand that looks real but feels fake. "Lady Letitia's Lilliput Hand" suggests that using such a device will always eventually invite suspicion, a feeling that no prosthesis user from this period wished to evoke, since doing so would undermine her/his ability to pass.

The greatest resistance to "normative positivism" (the preference for normalcy) and "non-normative negativism" (disablism) that Buchanan's short story provides comes in the form of the non-normative marital success that Lady Lilliput eventually achieves. ${ }^{115}$ Ultimately, she is able to recapture Vansittart's affection and marry him-not by concealing her use of a prosthesis but by revealing its artificiality and the scandalous back story that its use conceals. Kafer's concept of "crip time" provides an illuminating model for Buchanan's representation as not merely conforming to, but rather disrupting, ableist traditions. Kafer conceptualizes "crip time" in opposition to common curative trends in imagining disabled futurity, which see disability as something that should be avoided or cured at all costs. According to ableist thinking, the only conceivable alternative to being cured is a life of "unending tragedy." Kafer instead seeks to imagine "more accessible futures, ... [a] yearning for an elsewhere-and, perhaps, an 'elsewhen'-in which disability is understood otherwise: as political, as valuable, as integral."116 In other words, Kafer's project is to challenge the ableist thinking in our present that affects the real and imagined futures of people living with disabilities. It would be remiss to say that "Lady Letitia's Lilliput Hand" participates in this kind of disruptive and progressive crip project, but what can be argued is that the disabled future that it imagines for the amputee Lady Lilliput is one that resists the hegemonic normative ways of thinking about disabled women in relation to marital futures. Lady Letitia can thus be understood in relation to the transgressive, bold, and sexually active disabled female characters of Wilkie Collins's sensation fiction-Madonna Blyth of Hide and Seek (1854) and Lucilla Finch of Poor Miss Finch (1872), most notably. ${ }^{17}$ Unlike these novels, or indeed the "familiar" disabled marriage narratives described by Schaffer-which present disabled characters as integral parts of domestic marital family networks - here Buchanan's work provides a direct affront to the normative positivism engendered by the curative concept of the concealing prosthesis, since the narrative emphasizes the success and attraction of disavowing passing as the primary prerogative for a prosthesis user. ${ }^{118}$ Vansittart's decision to keep hold of the Lilliput Hand after his 
wife's death is at once fetishistic and reveals a transgressive fondness for physical difference.

Clearly, many nineteenth-century writers were fascinated by the marital prospects facing prosthesis users, highlighting the growing influence of prosthesis culture within the Victorian imagination. But when considered together, there seems to be little consensus regarding how prosthesis users should be treated in literary writings. On the one hand, prostheses were often represented, in particular when used by women, as devices that might disqualify the user from the marriage market. But on the other, they were sometimes imagined as either tolerable or outright attractive for a wide variety of reasons: they could kindle sympathy and "love which conquers all reversals and disabilities"; they could signify wealth and social status or be economically valuable in their own right; they could be used to attract other prosthesis users; or they could themselves be aesthetically pleasing fetish objects whose artificiality is made manifest. As this chapter shows, such representations shed light on the complex and variegated ways that gender inflected attitudes to physical wholeness, difference, and the devices used to conceal it. Fictional marriage plots tended to focus on fitness, productive potential, and social status, sometimes providing more leeway to male prosthesis users compared to their female equivalents. Representations of female prosthesis users, meanwhile, often centred on tensions between the visibility and the invisibility of their devices and the perceived honesty of the user. Considered together, these sources provide evidence of how unstable literary attitudes were regarding the concept of physical wholeness. Plainly, ableism and patriarchalism were entangled influences in the period investigated, and yet both male and female prosthesis users remained conspicuously and ironically visible in the literary works of a society that proved increasingly interested in concealing such differences from public view.

\section{Notes}

1. American limb maker John S. Drake used whale ivory in the construction of his devices. See John S. Drake, Drake's Patent Artificial Legs, Hands, Arms, oc. (Boston: J. Drake, 1859). Also see Chapter 2, especially the discussion of Ahab's ivory leg in Herman Melville's Moby-Dick (1850).

2. Martha Stoddard Holmes, Fictions of Affliction: Physical Disability in Victorian Culture (Ann Arbor: University of Michigan Press, 2004); Talia Schaffer, Romance's Rival: Familiar Marriage in Victorian Fiction (Oxford: Oxford University Press, 2016). 
3. Ian Watt, The Rise of the Novel: Studies in Defoe, Richardson, and Fielding (Berkeley: University of California Press, 1974); Lawrence Stone, The Family, Sex and Marriage in England 1500-1800 (London: Penguin Books, 1990); Nancy Armstrong, Desire and Domestic Fiction: A Political History of the Novel (Oxford: Oxford University Press, 1987); Ruth Perry, Novel Relations: The Transformation of Kinship in English Literature and Culture, 1748-1818 (Cambridge: Cambridge University Press, 2004); Helena Michie, Victorian Honeymoons: Journeys to the Conjugal (Cambridge: Cambridge University Press, 2006); Helena Michie, Love among the Archives (Edinburgh University Press, 2015); Sharon Marcus, Between Women: Friendship, Desire, and Marriage in Victorian England (Princeton: Princeton University Press, 2007); Elsie B. Michie, The Vulgar Question of Money: Heiresses, Materialism, and the Novel of Manners from Jane Austen to Henry James (Baltimore: Johns Hopkins University Press, 2011); Maia McAleavey, The Bigamy Plot: Sensation and Convention in the Victorian Novel (Cambridge: Cambridge University Press, 2015); Schaffer, Romance's Rival.

4. Cindy LaCom, "'Is It More than Lame': Female Disability, Sexuality, and the Maternal in the Nineteenth-Century Novel," in The Body and Physical Difference: Discourses of Disability, ed. Sharon L. Snyder and David T. Mitchell (Ann Arbor: University of Michigan Press, 1997); Holmes, Fictions; Schaffer, Romance's Rival.

5. Holmes, Fictions, 35.

6. Ibid., 72-73.

7. Ibid., 74 .

8. Schaffer, Romance's Rival, 2-3.

9. Ibid., 160.

10. See Bruce Haley, The Healthy Body and Victorian Culture (Cambridge: Harvard University Press, 1978), 3-22; Erin O'Connor, Raw Material: Producing Pathology in Victorian Culture (Durham: Duke University Press, 2000), 104-106; Katherine Ott, "Hard Wear and Soft Tissue: Craft and Commerce in Artificial Eyes," in Artificial Parts, Practical Lives: Modern Histories of Prosthetics, eds. Katherine Ott, David Serlin, and Stephen Mihm (New York: New York University Press, 2002), 152-53; and Stephen Mihm, "'A Limb Which Shall Be Presentable in Polite Society': Prosthetic Technologies in the Nineteenth Century," in Artificial Parts, Practical Lives: Modern Histories of Prosthetics, eds. Katherine Ott, David Serlin, and Stephen Mihm (New York: New York University Press, 2002).

11. William Dodd, "A Narrative of the Experience and Sufferings of William Dodd, A Factory Cripple. Written by Himself," in Factory Lives: Four Nineteenth-Century Working-Class Autobiographies, ed. James R. Simmons Jr. (London: Broadview, 2007). 
12. Ibid., 211.

13. Ibid.

14. Ibid., 201.

15. Mihm, “A Limb,” 288.

16. Oliver Wendell Holmes, "The Human Wheel, Its Spokes and Felloes," in Sounds from the Atlantic, by Oliver Wendell Holmes (Boston: Ticknor and Fields, 1864), 306-307.

17. Auguste Boissonneau, General Observations on Artificial Eyes, Their Adaption, Employment and the Means of Procuring Them (Paris: J.-B. Baillière and Son, 1862), 5.

18. Holmes, Fictions, 63.

19. Henry Maudsley, "Galstonian Lecture II on Relations between Body and Mind, and between Mental and Other Disorders of Nervous System," Lancet, April 30, 1870, 609-10; qtd. in Holmes, Fictions, 66-68.

20. Alexander Walker, Intermarriage; or the Mode in Which, and the Causes Why, Beauty, Health, and Intellect Result from Certain Unions, and Deformity, Disease and Insanity from Others (London: John Churchill, $1838), 324$.

21. See Shirley Foster, Victorian Women's Fiction: Marriage, Freedom, and the Individual (London: Routledge, 2012); Mary Lyndon Shanley, Feminism, Marriage, and the Law in Victorian England (Princeton: Princeton University Press, 1993); and Ben Griffin, The Politics of Gender in Victorian Britain: Masculinity, Political Culture and the Struggle for Women's Rights (Cambridge: Cambridge University Press, 2012).

22. See Helena Michie, The Flesh Made Word: Female Figures and Women's Bodies (Oxford: Oxford University Press, 1987); Mary Poovey, Uneven Developments the Ideological Work of Gender in Mid-Victorian England (Chicago: University of Chicago Press, 1988); Athena Vrettos, Somatic Fictions: Imagining Illness in Victorian Culture (Stanford: Stanford University Press, 1995); Pamela K. Gilbert, Disease, Desire and the Body in Victorian Women's Popular Novels (Cambridge: Cambridge University Press, 1997); Alison Bashford, Purity and Pollution: Gender, Embodiment, and Victorian Medicine (Basingstoke: Palgrave Macmillan, 1998); and Andrew Mangham and Greta Depledge, The Female Body in Medicine and Literature (Liverpool: Liverpool University Press, 2013).

23. Carl Heinrich Stratz, Die Schönheit des weiblichen Körpers, 14th ed. (Stuttgart: F. Enke, 1903); Havelock Ellis, Man and Woman: A Study of Human Secondary Sexual Characters (London: Walter Scott, 1904).

24. "Damages for an Eye: What Would Compensate for Mental Anguish and Disability?" New York Times, December 4, 1909.

25. Samuel H. Williamson, "Seven Ways to Compute the Relative Value of a U.S. Dollar Amount, 1774 to Present," Measuring Worth, accessed July 19, 2021, www.measuringworth.com/uscompare/. 
26. "Damages for an Eye," 10.

27. "The Lame Landlord's Story," Temple Bar 20 (1867): 127.

28. William Blanchard Jerrold, "Eyes Made to Order," Household Words 4, no. 81 (1851): 64.

29. "The False Hair," Chambers's Journal of Popular Literature, Science and Arts 8, no. 396 (1861): [65]-67.

30. "Her Fatal Sneeze," Illustrated Chips, no. 2 (1890): 26; "The Stricken Fawn." Fun 58, no. 1489 (1893): 219.

31. "Her Fatal Sneeze," 26.

32. Simon Dickie, "Hilarity and Pitilessness in the Mid-Eighteenth Century: English Jestbook Humor," Eighteenth-Century Studies 37, no. I (2003); Simon Dickie, Cruelty and Laughter: Forgotten Comic Literature and the Unsentimental Eighteenth Century (Chicago: University of Chicago Press, 2011).

33. John Storey, The Making of English Popular Culture (London: Routledge, 2016).

34. Prices here are taken from the following sources: Holborn Dental Institute, "Advertisement for the Holborn Dental Institute," 1886, British Library Online Gallery, accessed July 5, 2018, http://www.bl. uk/onlinegallery/onlineex/evancoll/a/014eva000000000u05139000. html; Mr. Foley, Surgeon Dentist, “Advertisement for Mr. Foley, Surgeon Dentist," c.1896, Wellcome Collection, accessed July 5, 2018, https:// wellcomecollection.org/works/j625k4vh.

35. "The Stricken Fawn."

36. Holmes, Fictions, 38.

37. "Too Hard upon My Aunt," All the Year Round 10, no. 242 (1863); A. M., "Was She False?" The London Reader: Of Literature, Science, Art and General Information 26, no. 656 (1875); "Kitty the Careless," Judy, August 1, 1883; Ryan Sweet, "Get the Best Article in the Market': Prostheses for Women in Nineteenth-Century Literature and Commerce," in Rethinking Modern Histories of Prostheses in Anglo-American Commodity Cultures, 1850-1960, ed. Claire L. Jones (Manchester: Manchester University Press, 2017), 126.

38. Thomas Hardy, The Woodlanders (Oxford: Oxford University Press, 2009).

39. Penny Boumelha, "Introduction," in The Woodlanders, by Thomas Hardy (Oxford: Oxford University Press, 2009), xxvi.

40. Edgar Allan Poe, "The Spectacles," in Prose Tales (Second Series) Arthur Gordon Pym, by Edgar Allan Poe (Boston: Dana Estes, 1884).

41. Hardy, The Woodlanders, 13.

42. Ibid., 220.

43. Ellen Wood, East Lynne (Oxford: Oxford University Press, 2008). 
44. Louisa May Alcott, Behind a Mask: or, A Woman's Power, in Louisa May Alcott Unmasked: Collected Thrillers, ed. Madeleine Stern (Boston: Northeastern University Press, 1995).

45. Tracy C. Davis, "Actresses and Prostitutes in Victorian London," Theatre Research International 13, no. 3 (1988): 221-34.

46. A. M., "Was She," 76.

47. “Women. By Our Office Boy.” Pick-Me-Up, no. 194 (1892): 189.

48. "Pepper and Salt," Judy, July 14, 1886, 20.

49. Thomas Hardy, Jude the Obscure (Oxford: Oxford University Press, 2008).

50. Ibid., 53.

51. Ibid.

52. Hardy, Jude, 53.

53. Sweet, "Get the Best," 130.

54. Margrit Shildrick, Leaky Bodies and Boundaries: Feminism, Postmodernism and (Bio)Ethics (London: Routledge, 1997), 55.

55. Sandra Lee Bartky, "Foucault, Femininity and Patriarchal Power," in Feminism and Foucault: Reflections on Resistance, eds. Irene Diamond and Lee Quinby (Boston: Northeastern University Press, 1988), 81.

56. Shildrick, Leaky Bodies, 56.

57. J. Capp, "Rewination!" The Sporting Times, December 8, 1888, no lines.

58. Jonathan Swift, "A Beautiful Young Nymph Going to Bed," Poetry Foundation, accessed July 2, 2018, https://www.poetryfoundation.org/ poems $/ 50580 /$ a-beautiful-young-nymph-going-to-bed.

59. G. W. C., "Good Advice and a Wooden Leg," Hearth and Home: An Illustrated Weekly Journal for Gentlewomen, no. 116 (1893): 419.

60. Oliver Wendell Holmes, "The Human Wheel, Its Spokes and Felloes," in Sounds from the Atlantic, by Oliver Wendell Holmes (Boston: Ticknor and Fields, 1864), 307.

61. André de Blaumont, "My Fiancé's Glass Eye," in Short Stories: A Magazine of Select Fiction, ed. Alfred Ludlow White, trans. Mrs. Huntington Denton, vol. XV (New York: The Current Literature Publishing Co., 1894); Andree de Beaumont, "My Fiancé's Glass Eye," The Sacred Heart Review 1, no. 1 (1895): 16.

62. de Beaumont, “My Fiancé's Glass,” 16.

63. See Jennifer Esmail, “The Little Dog Is Only a Stage Property': The Blind Man's Dog in Victorian Culture," Victorian Review 40, no. $1(2014)$.

64. de Beaumont, “My Fiancé's Glass,” 16.

65. David Serlin, "Engineering Masculinity: Veterans and Prosthetics after World War Two," in Artificial Parts, Practical Lives: Modern Histories of Prosthetics, eds. Katherine Ott, David Serlin, and Stephen Mihm (New York: New York University Press, 2002), 52. 
66. Charlotte Brontë, Jane Eyre, 3rd ed. (London: Norton, 2001). Of course, from a feminist or critical disability-studies perspective it is easy to critique the morality of Rochester's actions leading up to the fire-keeping Bertha Mason locked in his attic being his most egregious - but to a Victorian reader his attempt to rescue her was clearly intended be read as heroic and/or redemptive. His impairments serve a double narrative function as embodied punishments for his past transgressions and emblems of his renewed chivalric character.

67. John Reynders \& Co., Illustrated Catalogue and Price List of Surgical Instruments, Spectacles, Eyeglasses, Optical Goods, Orthopaedical Apparatus, Trusses, Supporters, Etc. Etc. (New York: John Reynders \& Co., 1889), 73; Williamson, "Seven Ways."

68. Charles Lenz \& Sons, Charles Lenz \& Sons' Illustrated Catalogue and Price List of Surgical Instruments, Hospital Supplies, Orthopaedical Apparatus, Trusses, Etc., 4th ed. (Philadelphia: Charles Lenz \& Sons, 1892), 78; Williamson, "Seven Ways."

69. Charles Truax, Greene \& Co., Price List of Physicians' Supplies (Chicago: Charles Truax, Greene \& Co., 1893), 1174 and 1162; Williamson, "Seven Ways."

70. Down Bros., A Catalogue of Surgical Instruments and Appliances Manufactured and Sold by Down Bros (London: Down Bros., 1890), 464; Lawrence H. Officer and Samuel H. Williamson, "Five Ways to Compute the Relative Value of a UK Pound Amount, 1270 to Present," Measuring Worth, accessed July 3, 2018, www.measuringworth.com/uscompare/.

71. Lawrence H. Officer and Samuel H. Williamson, "Annual Wages in the United States, 1774-Present," Measuring Worth, accessed July 6, 2018, http://www.measuringworth.com/USwages/; Gregory Clark, "What Were the British Earnings and Prices Then? (New Series)," Measuring Worth, accessed July 6, 2018. http://www.measuringworth.com/ ukearncpi/.

72. Richard Corson, Fashions in Eyeglasses (London: Peter Owen, 1980), 114.

73. Marius Hentea, "Monocles on Modernity," Modernism/Modernity 20, no. 2 (2013).

74. Peter Stoneley, Mark Twain and the Feminine Aesthetic (Cambridge: Cambridge University Press, 1992), 32.

75. Charles Dickens, Barnaby Rudge (Oxford: Oxford University Press, 2003); Charles Dickens, Dombey and Son, Project Gutenberg, last modified September 25, 2016, https://www.gutenberg.org/files/821/821h/821-h.htm.

76. Dickens, Dombey, ch. 32.

77. Ibid., ch. 4.

78. Ibid., ch. $4,17,50$. 
79. Ibid., ch. 9.

80. Ibid., ch. 15 .

81. Ibid., ch. 32 .

82. Ibid., ch. 39.

83. Ibid., ch. 23 .

84. Ibid.

85. Jerrold, "Eyes," 65.

86. Dickens, Dombey, ch. 9.

87. Ibid., ch. 15.

88. Schaffer, Romance's Rival, 196.

89. Dickens, Dombey, ch. 60.

90. John Jordan, “Openings” (lecture, Dickens Universe 2016, University of California, Santa Cruz, July 31, 2016).

91. Geoffry Brandon, "The Story of the Jewel in the Stage Coach as Related by Simon Simple Barrister-at-Law," The Ludgate 8 (1899).

92. Ibid., 540-42.

93. "He Fixed Her with His Glassy Eye," Cheshire Observer, April 5, 1879, 3.

94. Clark, "What Were."

95. Vanessa Warne, “'To Invest a Cripple with Peculiar Interest': Artificial Legs and Upper-Class Amputees at Mid-Century," Victorian Review 35, no. 2 (2009): 97.

96. Ibid., 94.

97. [Smith], “The Lucky,” 380.

98. M. Sullivan, Stronger Than Death, ch. 17-20, The New Monthly Magazine 146, no. 593 (1870): 492.

99. Heinrich Zschokke, “Das Bein," Erheiterungen 1 (1811).

100. [Heinrich Zschokke], "The Leg-a True Story," The Kaleidoscope: or, Literary and Scientific Mirror 7, no. 365 (1827).

101. [Heinrich Zschokke], “The Leg," Bentley's Miscellany 3 (1838); [Heinrich Zschokke], “The Leg," Chambers's Edinburgh Journal, no. 376 (1839); [Heinrich Zschokke], "The Leg," The Penny Satirist, no. 375 (1844); [Heinrich Zschokke], “The Leg," Bristol Mercury, January 24, 1857; [Heinrich Zschokke], “The Leg," Santa Fe New Mexican, April 4, 1899; [Heinrich Zschokke], "Was He a Madman?”, Bow Bells: A Magazine of General Literature and Art for Family Reading 19, no. 484 (1873); [Heinrich Zschokke], "Losing a Leg to Gain a Wife," Hampshire Telegraph and Sussex Chronicle Etc., April 4, 1885; [Heinrich Zschokke], "Love's Amputation; or, A Leg for a Lady," Hampshire Telegraph and Sussex Chronicle Etc., March 7, 1891; [Heinrich Zschokke], "Giving a Limb for a Wife, with Future Regrets," Bossier Banner, April 16, 1891; [Heinrich Zschokke], “A Case in Surgery. Which Shows That a Man May Do Too Much for Love of Woman," trans. E. C. Waggener, National Tribune, February 2, 1893. 
102. [Heinrich Zschokke], "The Leg—a True Story," Wilmingtonian, and Delaware Advertiser, May 24, 1827, front page.

103. Michael Oliver, The Politics of Disablement (Basingstoke: Macmillan Education, 1990).

104. Alison Kafer, Feminist, Queer, Crip (Bloomington: Indiana University Press, 2013), 2.

105. [Zschokke], “The Leg—a True Story," front page.

106. [Robert Williams Buchanan], "The Fleshly School of Poetry," Contemporary Review 18 (1871): 334-50.

107. Robert Williams Buchanan, "Lady Letitia's Lilliput Hand," Temple Bar 4 and 5 (1862), 552.

108. Michie, The Flesh, 98.

109. Clare Stainthorp, "Activity and Passivity: Class and Gender in the Case of the Artificial Hand," Victorian Literature and Culture 45, no. I (2017): 9.

110. David Bolt, "Not Forgetting Happiness: The Tripartite Model of Disability and Its Application in Literary Criticism," Disability \& Society 30, no. 7 (2015).

111. Buchanan "Lady Letitia's," 131.

112. Henry Heather Bigg, On Artificial Limbs, Their Construction and Application (London: John Churchill, 1855).

113. Pamela K. Gilbert, "The Will to Touch: David Copperfield's Hand," 19: Interdisciplinary Studies in the Long Nineteenth Century, October 2014, http://19.bbk.ac.uk/articles/10.16995/ntn.695/; Stainthorp, "Activity."

114. Martha Stoddard Holmes and Mark Mossman, "Disability in Victorian Sensation Fiction," in A Companion to Sensation Fiction, ed. Pamela K. Gilbert (Chichester: Wiley-Blackwell, 2011), 493-94.

115. Bolt, "Not Forgetting."

116. Kafer, Feminist, 3.

117. Wilkie Collins, Hide and Seek (Oxford: Oxford University Press, 2009); Wilkie Collins, Poor Miss Finch (Oxford: Oxford University Press, 2008).

118. Schaffer, Romance's Rival, 160-98.

\section{REFERENCES}

Alcott, Louisa May. Behind a Mask: or, A Woman's Power. In Louisa May Alcott Unmasked: Collected Thrillers, edited by Madeleine Stern, 361-429. Boston: Northeastern University Press, 1995.

A. M. "Was She False?" The London Reader: Of Literature, Science, Art and General Information 26, no. 656 (1875): 75-76.

Armstrong, Nancy. Desire and Domestic Fiction: A Political History of the Novel. Oxford: Oxford University Press, 1987. 
Bartky, Sandra Lee. "Foucault, Femininity and Patriarchal Power." In Feminism and Foucault: Reflections on Resistance, edited by Irene Diamond and Lee Quinby, 61-86. Boston: Northeastern University Press, 1988.

Bashford, Alison. Purity and Pollution: Gender, Embodiment, and Victorian Medicine. Studies in Gender History. Basingstoke: Palgrave Macmillan, 1998.

Beaumont, Andree de. "My Fiancé's Glass Eye." The Sacred Heart Review 1, no. 1 (1895): 16.

Bigg, Henry Heather. On Artificial Limbs, Their Construction and Application. London: John Churchill, 1855.

Blaumont, André de. "My Fiancé's Glass Eye." In Short Stories: A Magazine of Select Fiction, edited by Alfred Ludlow White, translated by Mrs. Huntington Denton, vol. XV: 277-81. New York: The Current Literature Publishing Co., 1894.

Boissonneau, Auguste. General Observations on Artificial Eyes, Their Adaption, Employment and the Means of Procuring Them. Paris: J.-B. Baillière and Son, 1862.

Bolt, David. "Not Forgetting Happiness: The Tripartite Model of Disability and Its Application in Literary Criticism." Disability \& Society 30, no. 7 (2015): 1103-17.

Boumelha, Penny. "Introduction." In The Woodlanders, by Thomas Hardy, xixxvi. Oxford: Oxford University Press, 2009.

Brandon, Geoffry. "The Story of the Jewel in the Stage Coach as Related by Simon Simple Barrister-at-Law." The Ludgate 8 (1899): 536-44.

Brontë, Charlotte. Jane Eyre. 3rd ed. London: Norton, 2001.

Buchanan, Robert Williams. "Lady Letitia's Lilliput Hand." Temple Bar 4 and 5 (1862): 551-69; 114-31.

[Buchanan, Robert Williams]. "The Fleshly School of Poetry." Contemporary Review 18 (1871): 334-50.

Capp, J. “Rewination!” The Sporting Times, December 8, 1888.

Charles Lenz \& Sons. Charles Lenz \& Sons' Illustrated Catalogue and Price List of Surgical Instruments, Hospital Supplies, Orthopaedical Apparatus, Trusses, Etc. 4th ed. Philadelphia: Charles Lenz \& Sons, 1892.

Charles Truax, Greene \& Co. Price List of Physicians' Supplies. Chicago: Charles Truax, Greene \& Co., 1893.

"He Fixed Her with His Glassy Eye". Cheshire Observer, April 5, 1879.

Clark, Gregory. "What Were the British Earnings and Prices Then? (New Series)." Measuring Worth. Accessed July 6, 2018. http://www.measuringworth.com/ ukearncpi/.

Collins, Wilkie. Hide and Seek. Oxford: Oxford University Press, 2009.

- Poor Miss Finch. Oxford: Oxford University Press, 2008.

Corson, Richard. Fashions in Eyeglasses. London: Peter Owen, 1980. 
"Damages for an Eye: What Would Compensate for Mental Anguish and Disability?" New York Times, December 4, 1909.

Davis, Tracy C. "Actresses and Prostitutes in Victorian London." Theatre Research International 13, no. 3 (1988): 221-34.

Dickens, Charles. Barnaby Rudge. Oxford: Oxford University Press, 2003.

—. Dombey and Son. Project Gutenberg. Last modified September 25, 2016. https://www.gutenberg.org/files/821/821-h/821-h.htm.

Dickie, Simon. "Hilarity and Pitilessness in the Mid-Eighteenth Century: English Jestbook Humor." Eighteenth-Century Studies 37, no. 1 (2003): 1-22.

- Cruelty and Laughter: Forgotten Comic Literature and the Unsentimental Eighteenth Century. Chicago: University of Chicago Press, 2011.

Dodd, William. "A Narrative of the Experience and Sufferings of William Dodd, A Factory Cripple. Written by Himself." In Factory Lives: Four NineteenthCentury Working-Class Autobiographies, edited by James R. Simmons Jr., 181-300. London: Broadview, 2007.

Down Bros. A Catalogue of Surgical Instruments and Appliances Manufactured and Sold by Down Bros. London: Down Bros., 1890.

Drake, John S. Drake's Patent Artificial Legs, Hands, Arms, \&oc. Boston: J. Drake, 1859.

Ellis, Havelock. Man and Woman: A Study of Human Secondary Sexual Characters. London: Walter Scott, 1904.

Esmail, Jennifer. “'The Little Dog Is Only a Stage Property': The Blind Man's Dog in Victorian Culture." Victorian Review 40, no. l (2014): 18-23.

"The False Hair". Chambers's Journal of Popular Literature, Science and Arts 8, no. 396 (1861): [65]-67.

Foster, Shirley. Victorian Women's Fiction: Marriage, Freedom, and the Individual. London: Routledge, 2012.

Gilbert, Pamela K. Disease, Desire and the Body in Victorian Women's Popular Novels. Cambridge: Cambridge University Press, 1997.

—. "The Will to Touch: David Copperfield's Hand." 19: Interdisciplinary Studies in the Long Nineteenth Century, October 2014. http://19.bbk.ac.uk/ articles/10.16995/ntn.695/.

Griffin, Ben. The Politics of Gender in Victorian Britain: Masculinity, Political Culture and the Struggle for Women's Rights. Cambridge: Cambridge University Press, 2012.

G. W. C. "Good Advice and a Wooden Leg." Hearth and Home: An Illustrated Weekly Journal for Gentlewomen, no. 116 (1893): 419.

Haley, Bruce. The Healthy Body and Victorian Culture. Cambridge: Harvard University Press, 1978.

Hardy, Thomas. The Woodlanders. Oxford: Oxford University Press, 2009.

- Jude the Obscure. Oxford: Oxford University Press, 2008. 
Hentea, Marius. "Monocles on Modernity." Modernism/Modernity 20, no. 2 (2013): 213-37.

"Her Fatal Sneeze". Illustrated Chips, no. 2 (1890): 26.

Holborn Dental Institute. "Advertisement for the Holborn Dental Institute." 1886. British Library Online Gallery. Accessed July 5, 2018. http://www.bl. uk/onlinegallery/onlineex/evancoll/a/014eva000000000u05139000.html.

Holmes, Martha Stoddard. Fictions of Affliction: Physical Disability in Victorian Culture. Ann Arbor: University of Michigan Press, 2004.

Holmes, Martha Stoddard, and Mark Mossman. "Disability in Victorian Sensation Fiction." In A Companion to Sensation Fiction, edited by Pamela K. Gilbert, 493-506. Chichester: Wiley-Blackwell, 2011.

Holmes, Oliver Wendell. "The Human Wheel, Its Spokes and Felloes." In Sounds from the Atlantic, by Oliver Wendell Holmes, 282-327. Boston: Ticknor and Fields, 1864.

Hood, Thomas. Miss Kilmansegg and Her Precious Leg. In Selected Poems of Thomas Hood, edited by John Clubbe, 193-270. Cambridge: Harvard University Press, 1970.

Jerrold, William Blanchard. "Eyes Made to Order." Household Words 4, no. 81 (1851): 64-66.

John Reynders \& Co. Illustrated Catalogue and Price List of Surgical Instruments, Spectacles, Eyeglasses, Optical Goods, Orthopaedical Apparatus, Trusses, Supporters, Etc. Etc. New York: John Reynders \& Co., 1889.

Jordan, John. "Openings." Lecture to Dickens Universe 2016. University of California, Santa Cruz. July 31, 2016.

Kafer, Alison. Feminist, Queer, Crip. Bloomington: Indiana University Press, 2013. "Kitty the Careless". Judy, August 1, 1883.

LaCom, Cindy. "Is It More than Lame': Female Disability, Sexuality, and the Maternal in the Nineteenth-Century Novel." In The Body and Physical Difference: Discourses of Disability, edited by Sharon L. Snyder and David T. Mitchell, 189-201. Ann Arbor: University of Michigan Press, 1997.

“The Lame Landlord's Story”. Temple Bar 20 (1867): 127-34.

“Made-up Beauty". The Botanico-Medical Recorder 8, no. 2 (1839): 30.

Mangham, Andrew, and Greta Depledge. The Female Body in Medicine and Literature. Liverpool: Liverpool University Press, 2013.

Marcus, Sharon. Between Women: Friendship, Desire, and Marriage in Victorian England. Princeton: Princeton University Press, 2007.

Maudsley, Henry. "Galstonian Lecture II on Relations between Body and Mind, and between Mental and Other Disorders of Nervous System." Lancet, April 30, 1870, 609-10.

McAleavey, Maia. The Bigamy Plot: Sensation and Convention in the Victorian Novel. Cambridge: Cambridge University Press, 2015. 
Michie, Elsie B. The Vulgar Question of Money: Heiresses, Materialism, and the Novel of Manners from Jane Austen to Henry James. Baltimore: Johns Hopkins University Press, 2011.

Michie, Helena. The Flesh Made Word: Female Figures and Women's Bodies. Oxford: Oxford University Press, 1987.

- Victorian Honeymoons: Journeys to the Conjugal. Cambridge: Cambridge University Press, 2006.

- Love among the Archives. Edinburgh University Press, 2015.

Mihm, Stephen. "'A Limb Which Shall Be Presentable in Polite Society': Prosthetic Technologies in the Nineteenth Century." In Artificial Parts, Practical Lives: Modern Histories of Prosthetics, edited by Katherine Ott, David Serlin, and Stephen Mihm, 282-99. New York: New York University Press, 2002.

Mr. Foley, Surgeon Dentist. "Advertisement for Mr. Foley, Surgeon Dentist." c.1896. Wellcome Collection. Accessed July 5, 2018. https://wellcomecollection.org/works/j625k4vh.

O'Connor, Erin. Raw Material: Producing Pathology in Victorian Culture. Durham: Duke University Press, 2000.

Officer, Lawrence H., and Samuel H. Williamson. "Annual Wages in the United States, 1774-Present." Measuring Worth. Accessed July 6, 2018. http://www. measuringworth.com/USwages/.

Officer, Lawrence H. "Five Ways to Compute the Relative Value of a UK Pound Amount, 1270 to Present.” Measuring Worth. Accessed July 3, 2018. www. measuringworth.com/uscompare/.

Oliver, Michael. The Politics of Disablement. Basingstoke: Macmillan Education, 1990.

Ott, Katherine. "Hard Wear and Soft Tissue: Craft and Commerce in Artificial Eyes." In Artificial Parts, Practical Lives: Modern Histories of Prosthetics, edited by Katherine Ott, David Serlin, and Stephen Mihm, 147-70. New York: New York University Press, 2002.

"Pepper and Salt", Judy, July 14, 1886.

Perry, Ruth. Novel Relations: The Transformation of Kinship in English Literature and Culture, 1748-1818. Cambridge: Cambridge University Press, 2004.

Poe, Edgar Allan. "The Spectacles." In Prose Tales (Second Series) Arthur Gordon Pym, by Edgar Allan Poe, 161-98. Boston: Dana Estes, 1884.

Poovey, Mary. Uneven Developments the Ideological Work of Gender in MidVictorian England. Chicago: University of Chicago Press, 1988.

Schaffer, Talia. Romance's Rival: Familiar Marriage in Victorian Fiction. Oxford: Oxford University Press, 2016.

Serlin, David. "Engineering Masculinity: Veterans and Prosthetics after World War Two." In Artificial Parts, Practical Lives: Modern Histories of Prosthetics, edited by Katherine Ott, David Serlin, and Stephen Mihm, 45-74. New York: New York University Press, 2002. 
Shanley, Mary Lyndon. Feminism, Marriage, and the Law in Victorian England. Princeton: Princeton University Press, 1993.

Shildrick, Margrit. Leaky Bodies and Boundaries: Feminism, Postmodernism and (Bio)Ethics. London: Routledge, 1997.

[Smith, Sarah]. “The Lucky Leg.” Household Words 19, no. 469 (1859): 374-80.

Stainthorp, Clare. "Activity and Passivity: Class and Gender in the Case of the Artificial Hand." Victorian Literature and Culture 45, no. 1 (2017): 1-16.

Stone, Lawrence. The Family, Sex and Marriage in England 1500-1800. London: Penguin Books, 1990.

Stoneley, Peter. Mark Twain and the Feminine Aesthetic. Cambridge: Cambridge University Press, 1992.

Storey, John. The Making of English Popular Culture. London: Routledge, 2016.

Stratz, Carl Heinrich. Die Schönheit des weiblichen Körpers. 14th ed. Stuttgart: F. Enke, 1903.

“The Stricken Fawn”. Fun 58, no. 1489 (1893): 219.

Sullivan, M. Stronger Than Death. Ch. 17-20. The New Monthly Magazine 146, no. 593 (1870): 489-512.

Sweet, Ryan. "Get the Best Article in the Market': Prostheses for Women in Nineteenth-Century Literature and Commerce." In Rethinking Modern Histories of Prostheses in Anglo-American Commodity Cultures, 1850-1960, edited by Claire L. Jones, 114-36. Manchester: Manchester University Press, 2017.

Swift, Jonathan. “A Beautiful Young Nymph Going to Bed.” Poetry Foundation. Accessed July 2, 2018. https://www.poetryfoundation.org/poems/50580/ a-beautiful-young-nymph-going-to-bed.

“Too Hard upon My Aunt”. All the Year Round 10, no. 242 (1863): 381-84.

Vrettos, Athena. Somatic Fictions: Imagining Illness in Victorian Culture. Stanford: Stanford University Press, 1995.

Walker, Alexander. Intermarriage; or the Mode in Which, and the Causes Why, Beauty, Health, and Intellect Result from Certain Unions, and Deformity, Disease and Insanity from Others. London: John Churchill, 1838.

Warne, Vanessa. “'To Invest a Cripple with Peculiar Interest': Artificial Legs and Upper-Class Amputees at Mid-Century." Victorian Review 35, no. 2 (2009): 83-100.

Watt, Ian. The Rise of the Novel: Studies in Defoe, Richardson, and Fielding. Berkeley: University of California Press, 1974.

Williamson, Samuel H. "Seven Ways to Compute the Relative Value of a U.S. Dollar Amount, 1774 to Present.” Measuring Worth. Accessed July 19, 2021. www.measuringworth.com/uscompare/.

"Women. By Our Office Boy". Pick-Me-Up, no. 194 (1892): 189.

Wood, Ellen. East Lynne. Oxford: Oxford University Press, 2008.

Zschokke, Heinrich. "Das Bein.” Erheiterungen 1 (1811): 87-100. 
[Zschokke, Heinrich]. "The Leg—a True Story." The Kaleidoscope: or, Literary and Scientific Mirror 7, no. 365 (1827a): 427-28.

—_ "The Leg—a True Story." Wilmingtonian, and Delaware Advertiser, May $24,1827 \mathrm{~b}$.

—. "The Leg." Bentley's Miscellany 3 (1838): 480-84.

—. "The Leg." Chambers's Edinburgh Journal, no. 376 (1839): 94-95.

—. "The Leg." The Penny Satirist, no. 375 (1844): 4.

—. "The Leg." Bristol Mercury, January 24, 1857.

—. "Was He a Madman?" Bow Bells: A Magazine of General Literature and Art for Family Reading 19, no. 484 (1873): 367.

-. "Losing a Leg to Gain a Wife." Hampshire Telegraph and Sussex Chronicle Etc., April 4, 1885.

—. "Giving a Limb for a Wife, with Future Regrets." Bossier Banner, April 16, 1891a.

- "Love's Amputation; or, A Leg for a Lady." Hampshire Telegraph and Sussex Chronicle Etc., March 7, $1891 \mathrm{~b}$.

— . "A Case in Surgery. Which Shows That a Man May Do Too Much for Love of Woman." Translated by E. C. Waggener. National Tribune, February 2, 1893.

_. "The Leg." Santa Fe New Mexican, April 4, 1899.

Open Access This chapter is licensed under the terms of the Creative Commons Attribution 4.0 International License (http://creativecommons.org/licenses/ by $/ 4.0 /$ ), which permits use, sharing, adaptation, distribution and reproduction in any medium or format, as long as you give appropriate credit to the original author(s) and the source, provide a link to the Creative Commons licence and indicate if changes were made.

The images or other third party material in this chapter are included in the chapter's Creative Commons licence, unless indicated otherwise in a credit line to the material. If material is not included in the chapter's Creative Commons licence and your intended use is not permitted by statutory regulation or exceeds the permitted use, you will need to obtain permission directly from the copyright holder.

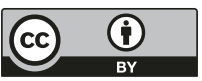

